\title{
The Overall Survival, Complication-Free Survival, and Related Complications of Combined Tooth-Implant Fixed Partial Dentures: A Literature Review
}

\author{
Peter Borg ${ }^{1}$, James Puryer ${ }^{2, *}$, Lisa McNally ${ }^{2}$ and Dominic O'Sullivan ${ }^{2}$ \\ 1 Regional Dental Clinic, Swieqi Road, Swieqi SWQ3410, Malta; peter.p.borg@gmail.com \\ 2 School of Oral and Dental Sciences, Bristol Dental Hospital, Lower Maudlin Street, Bristol BS1 2LY, UK; \\ L.M.McNally@bristol.ac.uk (L.M.); D.J.OSullivan@bristol.ac.uk (D.O.) \\ * Correspondence: james.puryer@bristol.ac.uk; Tel.: +44-117-342-4184; Fax: +44-117-342-4443
}

Academic Editor: Bernhard Pommer

Received: 21 March 2016; Accepted: 4 May 2016; Published: 25 May 2016

\begin{abstract}
This paper reviews the literature regarding possible complications, complication-free survival, and overall survival of fixed dental prostheses that use both implants and natural teeth as abutments. The paper also provides clinical guidelines for treatment based on this literature review. An electronic search utilizing the MEDLINE, BIOSIS Citation Index, and Web of Science ${ }^{\mathrm{TM}}$ Core Collection databases was undertaken, and a review of the 25 selected texts studying 22 different patient cohorts was carried out. From a total of 1610 implants reviewed, 40 were lost (33 due to loss of integration and 7 due to fracture), whereas, out of a total of 1301 teeth, 38 were lost, of which 16 were due to fracture. Seventy-three cases of tooth intrusion were detected. From a total of 676 frameworks reviewed (metal $n=645$, Zirconia $n=31$ ), 7 fractured, while veneer material fracture occurred in 70 out of 672 bridges. Overall, 502 out of 531 tooth-implant fixed prostheses (TIPFs) remained functional, and 336 out of 439 prostheses showed no technical or biological complications and remained functional. Rigid TIFPs permanently cemented to teeth with sufficient coronal structure and with limited use of prosthetic attachments offer a good long-term treatment option to patients with good oral hygiene following sound implant placement. This mode of treatment should be used when free-standing implant-supported options may not be possible. Larger randomized control studies and other clinical studies comparing tooth-to-implant-connected treatment with other forms of treatment are needed to better understand the place of TIFP treatment in oral rehabilitation.
\end{abstract}

Keywords: implant; survival; complications; fixed partial dentures

\section{Introduction}

Dental implants have originally been used with success in the treatment of edentulous patients [1,2], but more recently there has been a shift in their use towards the treatment of partially edentulous patients [3]. Implant treatment, including that of partially edentulous patients, has been proven to be successful, with favorable implant and implant-supported prosthesis survival rates $[4,5]$. One systematic review demonstrated an implant survival rate of $92-97 \%$ over a period of at least 5 years [4]. Similarly, a systematic review focusing on complications of implant-supported prostheses concluded that such dental prostheses had a survival rate of $96.4 \%$ after 5 years and $93.9 \%$ after 10 years [3]. Despite this, complications, both technical and biological, were frequent with up to $33.6 \%$ after 5 years [3].

Despite the positive results achieved with free-standing implant-supported fixed partial dentures (FPDs), certain clinical scenarios necessitate that root form implants be connected to natural teeth. 
Tooth-to-implant connection dates back to the early 1980's [6], and the connection of teeth to implants as a desirable, rather than a necessary, option was first explored in 1986 by Ericsson et al., who found that there was a satisfactory outcome with the use of osseointegrated titanium implants and teeth as abutments in the same fixed bridge reconstruction [7]. More recent studies have also demonstrated favorable results when connecting teeth and implants [8-11], with some studies showing similar treatment outcomes for tooth-to-implant and free-standing implant restorations [9].

Topic debate: The combination of natural teeth to dental implants was, and remains, a controversial topic in implant dentistry [12-14].

Clinical relevance: Clinical situations may arise where the connection of osseointegrated implants to teeth may be desirable. Such a scenario commonly arises in Kennedy Class I or II cases, where an implant may be connected to the terminal natural tooth via a three-unit bridge. Such a configuration would eliminate the need to place additional implants distal to the last natural tooth which, apart from increasing the cost, may be complicated by local factors such as reduced bone quantity or the presence of vital structures that would obstruct implant placement in that position. In such a case, avoiding complicated bone grafting procedures would decrease morbidity and the chance of complications. Such a technique may also preclude the need for cantilevered bridges supported by implants or teeth, which may not be desirable due to occlusal forces on the unsupported pontic.

The connection of teeth to implants can also be employed in long-span bridges involving many teeth and implants where strategically placed fixtures may be connected to the remaining teeth to restore the arch. In such cases, the use of teeth would simplify surgical treatment, reducing morbidity and cost while maintaining the periodontal ligament and corresponding proprioception from the natural teeth. Proprioception is particularly important in patients with bruxism, where the feedback from the remaining teeth may help to reduce stresses on the restoration $[9,15]$. In fact, it has been clinically demonstrated that there is an increased incidence of screw fracture and loosening as well as veneer fracture in free-standing implant-supported fixed prostheses (FSFPs) compared to tooth-implant fixed prostheses (TIPFs) [16]. Screw loosening is also more likely in bruxist patients in which the implants are overloaded with torsional force such as canines during guidance [6]. In these cases, the practitioner can reduce the susceptibility to torsional forces on the guiding tooth by splinting the implants to natural teeth as an anti-rotational measure. Preservation of the natural tooth may also aid in achieving a cosmetic result, which is often difficult to achieve with implant restorations, particularly when attempting to recreate the interdental papillae in the anterior region.

Biomechanics and concerns: The connection of implants to natural teeth presents a biomechanical challenge, due to the difference in mobility of the implant and tooth. A periodontally healthy tooth shows displacement values of around $28 \mu \mathrm{m}$ in the vertical direction during physiologic function [17] and $100-120 \mu \mathrm{m}$ in the horizontal direction when a force of approximately $5 \mathrm{~N}$ is obliquely applied to the crown, with posterior teeth exhibiting less horizontal movement than anterior teeth [18]. Conversely, osseointegrated implants show vertical displacement values of 2-3 $\mu \mathrm{m}$ under forces of $45 \mathrm{~N}$ [17], 12-66 $\mu \mathrm{m}$ in the labio-lingual direction [17], and $40-115 \mu \mathrm{m}$ in the mesio-distal direction under a force of $20 \mathrm{~N}$ [19].

The differences in displacement values demonstrate that teeth move more readily within the periodontal ligament (PDL) than osseointegrated implants within bone. This difference in mobility led to dispute over the possibility of rigidly connecting natural teeth to implants, and it was recommended that non-rigid connectors (NRCs) were used instead, with claims that occlusal loads would be taken by the implant, with the abutment tooth acting as a cantilever if rigidly connected to each other [7,20-22]. It was postulated that such implant overload would consequently lead to peri-implant bone resorption, eventual failure of the implant, prosthetic problems [23], and possible hypofunction of the natural tooth resulting in disuse atrophy of the periodontal structures [22].

More recently, a number of authors believe that there is sufficient flexibility within the implant-restoration unit (without a NRC) to allow for movement of the tooth within the socket to a degree where support is also achieved from the tooth [24,25], resulting in a more equal force 
distribution between the tooth and the implant [26]. The sharing of force may be partly due to prosthesis and abutment screw flexibility, particularly in this case where gold abutment screws are used that are inherently less rigid than the more commonly used titanium screws, partly due to fixture movement in the bone and partly due to the flexibility of the rigid prosthesis. Such claims of equal force distribution have been demonstrated clinically by the strain-gauge analysis of loads applied to prostheses [27]. This reasoning could prove the use of any mobile elements in the prostheses unnecessary and support the use of rigid prostheses when connecting natural teeth to implants.

Simply described, a vertical bite force causes movement of the tooth within the periodontal ligament, resulting in a moment of force around the implant. The magnitude of this moment depends on the mobility of the tooth and implant, the length and flexibility of the prosthesis and prosthetic components, and the flexibility of the bone. If sufficient mobility is achieved in the implant-restoration unit, and the tooth is firm within the socket, then support for the fixed partial denture will be achieved from both the implant and tooth, and long-term complications can be averted. However, in cases where the implant-restoration complex is not flexible or the tooth is lacking support, it is unlikely that prosthesis will gain any support from the natural tooth, which would instead act as a cantilever, justifying the concerns of clinicians wishing to insert NRCs. It is worth noting that minimal movement at the abutment implant junction will translate to a larger translation of the tooth in the socket.

The following factors affect the biomechanics of the tooth-to-implant connections [28]:

- mobility of the natural tooth;

- number of teeth and implants to be connected;

- occlusal forces including:

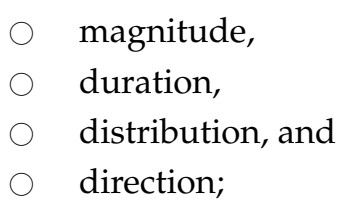

- $\quad$ the force absorbing properties of the veneering material;

- $\quad$ rigidity of the prosthesis including length, thickness, and connectors (rigid or non-rigid);

- type of bone.

Connection techniques: When the connection of teeth and implants is required via a prosthesis, there are two main designs that may be considered: a prosthesis with either a rigid or a NRC. Despite the theoretical support for non-rigid connection, a number of studies have demonstrated an association between the use of NRCs and complications, most notably tooth intrusion [29-31]. Apart from deciding on the type of connector to use, the clinician must also consider where to position it, either on the implant crown or natural tooth crown, and whether to include stress-absorbing elements between the implant and prosthesis [32,33] as was available with the now discontinued IMZ Intramobile element (IME) system. The use of telescopic crowns or copings with locking screws in combination with rigid connectors $[34,35]$ as well as cementation of the FPD with temporary cement for increased retrievability have been suggested.

Clinical complications: Along with the biomechanical problems that result from connecting natural teeth to implants, other issues may arise including problems related to the retrievability of the restoration, strain on the implant screw [36,37], framework and veneering material strain and fracture [36], tooth intrusion [38], and mechanical problems of the tooth.

(a) Retrievability: If a NRC is used with screw retention on the implant, then the implant portion of the reconstruction can easily be removed. If, on the other hand, a rigid construction is necessary, a one-piece casting will reduce retrievability because of the cement retention on the natural tooth abutment. To have a rigid restoration and maintain retrievability, a "screw-locked connector" 
may be installed in the restoration or a one-piece casting used with a telescopic crown on the natural tooth. This would be retained through the use of temporary cement or a locking screw.

(b) Implant screw loosening: The constant bending of the prosthesis caused by the disparity in implant and natural tooth mobility may result in the loosening of the screw or ultimately fatigue fracture [39].

(c) Framework and veneer fracture: Similarly, the constant bending of the restoration may lead to fracture of the framework and veneering material. The preference to keep the framework connectors narrow to increase the flexibility of framework must be balanced with the need for fracture resistance. The veneering material should also be flexible and preferably absorb some of the occlusal load without compromising material strength.

(d) Tooth intrusion: Possible reasons have been described, including diffuse atrophy, differential energy dissipation, mandibular flexure, fixed partial denture flexure, impaired rebound memory, debris impaction or microjamming, and the ratchet effect [38], yet the etiology for this phenomenon is not fully understood.

(e) Tooth or implant fracture: Conventional tooth-borne prostheses or FSFP fracture of the supporting tooth or fixture is a possibility [40], especially in cases where the tooth is heavily restored, and the root canal treated [31].

\section{Aims and Objectives}

\subsection{Aims}

To provide an overview of the literature regarding possible complications, complication-free survival and overall survival of fixed dental prostheses using both implants and natural teeth as abutments. The review will also strive to assess whether the literature currently available can provide sufficient data as to inform clinicians on how best to connect implants and teeth. If sufficient evidence is available, the aim is to then provide clinical guidelines for treatment in line with the available literature.

\subsection{Objectives}

- To assess which clinical situations are best suited for TIFPs.

- To determine overall survival and complication-free survival for TIFPs.

- To determine whether rigid or non-rigid connectors are the better option when connecting teeth to implants.

- To determine the potential of periodontally compromised and structurally compromised teeth to be used as abutments for TIFPs.

- To determine the best ways of attaching the framework to the natural teeth.

- To determine the ideal construction of TIFPs, including connectors, framework, and veneering.

\section{Methodology}

\subsection{Search Strategy}

An electronic search was performed via Web of Knowledge (Thomson Reuters TM) including the MEDLINE, BIOSIS Citation Index, Web of Science ${ }^{\mathrm{TM}}$ Core Collection databases in October 2014. Studies from 1984 to 2014 that were published in English were included in the search.

The following key words sequence was used to search titles:

TITLE: (tooth* or teeth* or partial*) AND TITLE: (implant* or implants* or fixture* or fixtures*) AND TITLE: (fixed partial denture* or prostheses* or prosthesis* or connected* or connection* or bridge ${ }^{*}$ or partial*).

The search results were reviewed, initially by title, and then by abstract. Copies of the remaining studies were obtained and subjected to a full text review applying the inclusion and exclusion criteria 
in order to determine the final list of studies to be included in this review. The PICO (Participants, Intervention, Comparison, and Outcome) Question used to focus the literature search is described in Table 1.

Table 1. PICO (Participants, Intervention, Comparison, and Outcome) Question used to focus literature search.

\begin{tabular}{ll}
\hline Participants & Partially Edentulous Patients Requiring Tooth-Implant Fixed Prostheses (TIPFs) Treatment \\
\hline \multirow{2}{*}{ Interventions } & $\begin{array}{l}\text { Rigid/non-rigid tooth-to-implant connection. } \\
\text { Permanent/temporary cement use for tooth cementation. } \\
\end{array}$ \\
& $\begin{array}{l}\text { Screw/cement retained for tooth/implant fixation. } \\
\text { Different framework and veneering materials. }\end{array}$ \\
\hline Comparison & Studies with similar interventions on tooth supported by FSFPs. \\
\hline \multirow{2}{*}{ Outcomes } & $\begin{array}{l}\text { Complications, complication-free survival, and overall survival of different tooth-to-implant } \\
\text { fixed prosthesis treatment modalities. }\end{array}$ \\
\hline
\end{tabular}

\subsection{Types of Studies Included}

- Studies published in peer-reviewed journals in English;

- Studies with at least ten participants;

- Randomized control studies;

- Prospective cohort studies;

- Retrospective cohort studies;

- Clinical trials including prospective and retrospective, controlled or uncontrolled and multicenter studies;

- Only studies utilizing commercially pure titanium implants were included.

\subsection{Types of Participants}

- Patients requiring tooth-to-implant fixed prosthesis treatment;

- Partially edentulous adult male and female patients, including smokers;

- Patients with fixed or removable opposing dentitions;

- Patients free from active periodontal disease.

\subsection{Types of Intervention}

- Tooth-to-implant fixed prostheses treatment in the maxilla and mandible;

- Tooth-to-implant connection with rigid and non-rigid connectors;

- Tooth connection utilizing telescopic crowns;

- Applications of temporary and permanent cements in tooth-to-implant cases;

- Sectional and full-arch cases;

- Application of different framework and veneering material for tooth-to-implant prostheses;

- Treatment utilizing vital and RCT teeth.

\subsection{Outcomes Recorded}

- Prosthetic complications including: veneer/framework fracture, abutment/implant fracture, cement failure, screw loosening, and loss of prosthesis;

- Biological complications including: tooth intrusion, dental caries, dental periapical pathology, tooth fracture, tooth bone loss, dental mobility, fixture bone loss, plaque deposits, and bleeding on probing. 


\subsection{Types of Excluded Studies/Exclusion Criteria}

- in vitro experiments;

- animal studies;

- case reports;

- literature reviews;

- $\quad$ studies making use of immediate implants or immediate loading of implants.

\subsection{Study Selection}

The initial electronic search via Web of Knowledge (Thomson Reuters ${ }^{\mathrm{TM}}$ ) including the MEDLINE, BIOSIS Citation Index and Web of Science ${ }^{\mathrm{TM}}$ Core Collection databases returned 1089 articles. The title and abstract were used to reduce the number of relevant articles to 39. The full texts of these 39 studies were procured and read. Eight authors were contacted to clarify parts of eight different studies, of which only five authors replied. Of the three that did not reply, one article was excluded, while the other two were retained. After applying the inclusion and exclusion criteria, 25 articles were selected for the literature review (Figure 1).

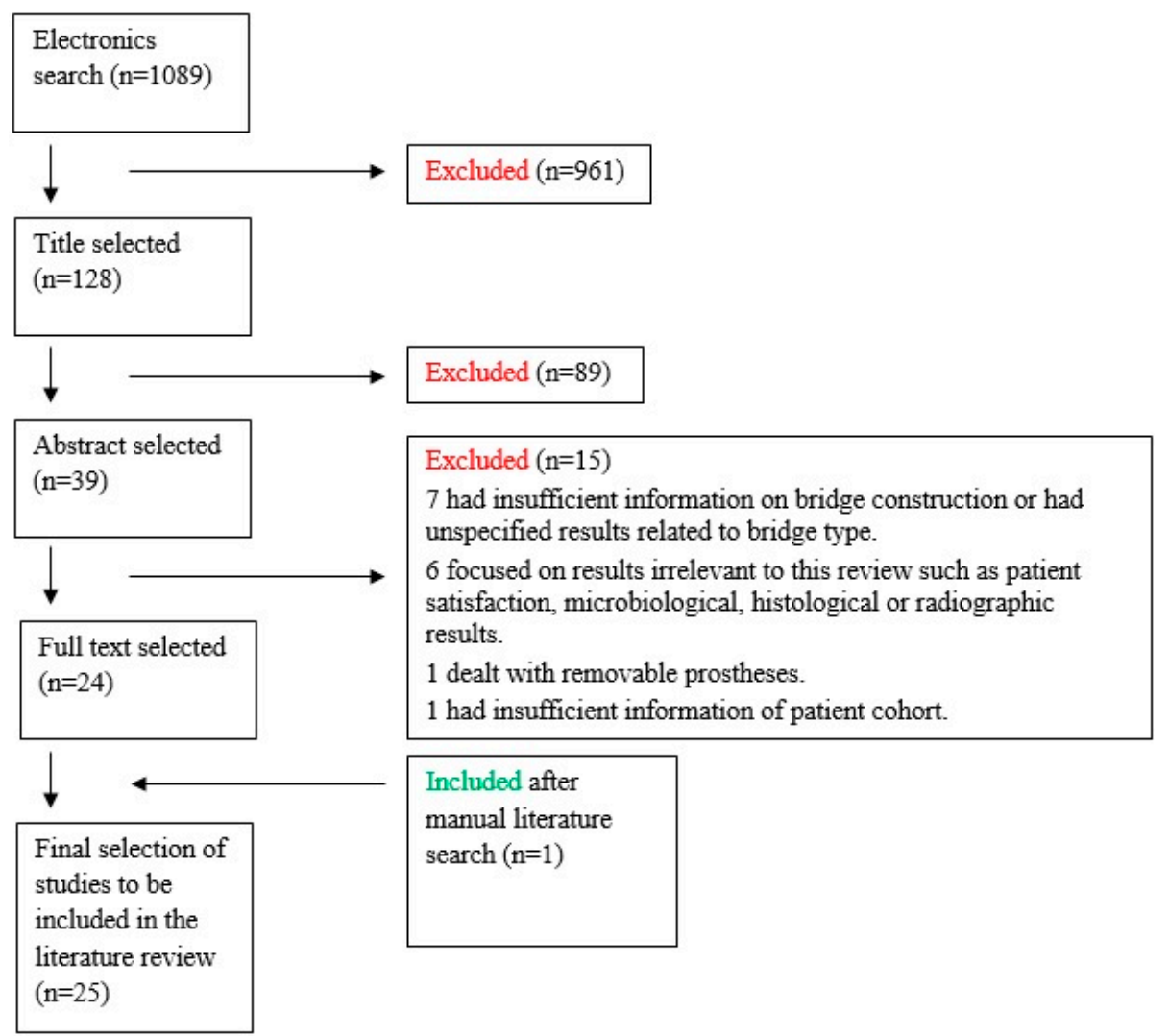

Figure 1. Flow chart of article selection.

\subsection{Study Validity and Clinical Relevance}

A number of the studies identified through the abstract dealt with implant rehabilitation as a whole, combining results for FSFPs and TIFPs together. These studies were not considered for this literature review. Further studies were excluded either because they failed to sufficiently describe the construction of the bridge or because the measured outcomes were not relevant to this review.

The 25 studies examined differed in their aims, methodologies, and data collection using several measures to assess TIFPs. Care was given in selecting the final studies, giving consideration to their 
clinical relevance and number of extraneous variables that would make it difficult in relating the causative factor to the obtained results.

The study outcomes noted can be broadly divided into two types:

Biological-related mainly to marginal bone levels around teeth and implants as well as to tooth intrusion and natural tooth condition including caries, periapical pathology, mobility and fracture, plaque accumulation, and gingival status.

Prosthetic - related to the implant and prosthesis including veneering material and framework condition, implant and implant abutment status, cement integrity, and implant screw loosening.

\subsection{Data Extraction and Analysis}

Each of the 25 included studies had their data extracted and inputted into a spreadsheet (Appendix 1) purposely designed for this study by a single reviewer. The spreadsheet included fields for the following data:

- $\quad$ study title, author names, publishing journal, and year of publication;

- institution where the study was conducted;

- type of study design;

- study aim;

- number of participants;

- number and type of prostheses, whether implant or tooth and implant-supported;

- bridge constructions;

- the periodontal condition of the teeth involved;

- the quality of the opposing dentition;

- method of prosthesis fixation to the supporting teeth and implants;

- observation period;

- biological and prosthetic complications.

Table 2 presents a list of all the studies selected for data extraction and analysis. Four of the studies followed the same cohort of patients over time [41-44]. Although all of the included studies were comparable, not all of the studies included answered all the questions asked by this critical review.

When it came to calculating overall prosthesis survival and complication-free survival, the prosthesis was used as the unit of measure. For the purpose of this study, overall survival refers to any prosthesis that remained functional in the mouth despite any complications that did not require remaking the restoration, and complication-free survival refers to prosthesis survival without any need for further treatment by the practitioner.

\subsection{Study Quality Assessment and Risk of Bias}

An assessment checklist based on that presented by Downs and Black in 1998 [45] was completed for each article in order to assess the quality of the study in relation to:

- Reporting;

- External validity—addressing the relevance of the findings to the general population;

- Bias-addressing bias in measuring the intervention and the measurement of the outcome;

- Selection bias - which addresses bias in subject selection;

- Power-attempting to determine whether the negative findings may be due to chance.

Each of the assessment questions were answered with a "Yes" contributing 1 point to the quality score, "No" not contributing to the quality score, or "Unable to determine" also not contributing to the score. Two criteria in the checklist had a variable scale, one from 0 to 2 and one from 0 to 5. 
Table 2. Table of articles selected for review.

\begin{tabular}{|c|c|c|c|c|c|c|c|c|}
\hline No. & Authors & Title & Source & Institute & Study Design & $\begin{array}{l}\text { No. of } \\
\text { Patients }\end{array}$ & Study Aim & $\begin{array}{l}\text { Observation } \\
\text { Period }\end{array}$ \\
\hline 1 & $\begin{array}{l}\text { Akca K, } \\
\text { Cehreli MC. }\end{array}$ & $\begin{array}{l}\text { Two-Year Prospective } \\
\text { Follow-up of } \\
\text { Implant/Tooth-Supported } \\
\text { Versus Freestanding } \\
\text { Implant-Supported Fixed } \\
\text { Partial Dentures. }\end{array}$ & $\begin{array}{l}\text { Int J Periodontics } \\
\text { Restorative Dent. } \\
2008,28,593-599\end{array}$ & $\begin{array}{l}\text { Faculty of Dentistry, } \\
\text { Hacettepe, } \\
\text { University, } \\
\text { Ankara, Turkey }\end{array}$ & $\begin{array}{l}\text { Prospective } \\
\text { case study }\end{array}$ & 29 & $\begin{array}{l}\text { To Compare prosthetic } \\
\text { outcomes of rigidly } \\
\text { connected short-span TIFPs } \\
\text { and FSFPs. }\end{array}$ & 24 months \\
\hline 2 & $\begin{array}{l}\text { Åstrand P, Borg K, } \\
\text { Gunne J, } \\
\text { Olsson M. }\end{array}$ & $\begin{array}{l}\text { Combination of Natural } \\
\text { Teeth and } \\
\text { Osseointegrated Implants } \\
\text { as Prosthesis Abutments: } \\
\text { A 2-Year } \\
\text { Longitudinal Study }\end{array}$ & $\begin{array}{l}\text { Int J Oral Maxillofac } \\
\text { Implants 1991, 6, } \\
\text { 305-312. }\end{array}$ & $\begin{array}{l}\text { Maxillofacial Unit } \\
\text { at the University } \\
\text { of Umeå }\end{array}$ & $\begin{array}{l}\text { Prospective case } \\
\text { study with } \\
\text { cross-arch } \\
\text { control; } \\
\text { Randomized }\end{array}$ & 23 & $\begin{array}{l}\text { To perform cross-arch } \\
\text { comparisons between FSFPs } \\
\text { and TIFPs. }\end{array}$ & 24 months \\
\hline 3 & $\begin{array}{l}\text { J Gunne, } \\
\text { Astrand P, } \\
\text { Ahlen K, Borg K, } \\
\text { Olsson M. }\end{array}$ & $\begin{array}{l}\text { Implants in partially } \\
\text { edentulou patients. } \\
\text { A longitudinal study of } \\
\text { bridges supported by } \\
\text { both implants and } \\
\text { natural teeth }\end{array}$ & $\begin{array}{l}\text { Clin. Oral. Impl. Res. } \\
\text { 1992, 3, 49-56 }\end{array}$ & $\begin{array}{l}\text { Maxillofacial Unit } \\
\text { at the University of } \\
\text { Umeå }\end{array}$ & $\begin{array}{l}\text { Prospective case } \\
\text { study with } \\
\text { cross-arch } \\
\text { control; } \\
\text { Randomized }\end{array}$ & 23 & $\begin{array}{l}\text { To compare the outcomes of } \\
\text { FSFPs with TIFPs. }\end{array}$ & 36 months \\
\hline 4 & $\begin{array}{l}\text { Olsson M, } \\
\text { Gunne J, } \\
\text { Astrand P, } \\
\text { Borg K. }\end{array}$ & $\begin{array}{l}\text { Bridges supported by } \\
\text { free-standing implants } \\
\text { versus bridges supported } \\
\text { by tooth and implant }\end{array}$ & $\begin{array}{l}\text { Clin. Oral. Impl. Res. } \\
\text { 1995, 6, 114-121 }\end{array}$ & $\begin{array}{l}\text { Maxillofacial Unit } \\
\text { at the University } \\
\text { of Umeå }\end{array}$ & $\begin{array}{l}\text { Prospective case } \\
\text { study with } \\
\text { cross-arch } \\
\text { control; } \\
\text { Randomized }\end{array}$ & 23 & $\begin{array}{l}\text { To evaluate the same bridges } \\
\text { as those presented in } 1991 \\
\text { after } 5 \text { years in function. }\end{array}$ & 60 months \\
\hline 5 & $\begin{array}{l}\text { Gunne F, } \\
\text { Ástrand P, } \\
\text { Lindh T, Borg K, } \\
\text { Olsson M. }\end{array}$ & $\begin{array}{l}\text { Tooth-Implant and } \\
\text { Implant Supported Fixed } \\
\text { Partial Dentures: } \\
\text { A 10-Year Report }\end{array}$ & $\begin{array}{l}\text { Int J Prosthodont } \\
1999,12,216-221 .\end{array}$ & $\begin{array}{l}\text { Maxillofacial Unit } \\
\text { at the University } \\
\text { of Umeå }\end{array}$ & $\begin{array}{l}\text { Prospective case } \\
\text { study with } \\
\text { cross-arch } \\
\text { control; } \\
\text { Randomized }\end{array}$ & $\begin{array}{l}23-20 \\
\text { attending at } \\
10 \text { years }\end{array}$ & $\begin{array}{l}\text { To compare FSFPs with TIFPs } \\
\text { after } 10 \text { years of function. }\end{array}$ & 120 months \\
\hline 6 & $\begin{array}{l}\text { Block MS, } \\
\text { Lirette D, } \\
\text { Gardiner D, } \\
\text { Li L, Finger IM, } \\
\text { et al. }\end{array}$ & $\begin{array}{l}\text { Prospective Evaluation of } \\
\text { Implants Connected } \\
\text { to Teeth. }\end{array}$ & $\begin{array}{l}\text { Int J Oral Maxillofac } \\
\text { Implants. 2002, 17, } \\
473-487\end{array}$ & $\begin{array}{l}\text { Authors affiliated } \\
\text { with the } \\
\text { Department of Oral } \\
\text { and Maxillofacial } \\
\text { Surgery, Louisiana } \\
\text { State University }\end{array}$ & $\begin{array}{l}\text { Prospective case } \\
\text { study with } \\
\text { cross-arch } \\
\text { control; } \\
\text { Randomized }\end{array}$ & 40 & $\begin{array}{l}\text { To examine the effect on teeth } \\
\text { and implants when rigidly or } \\
\text { non-rigidly connected in a } \\
\text { cross-arch study. }\end{array}$ & 60 months \\
\hline
\end{tabular}


Table 2. Cont

\begin{tabular}{|c|c|c|c|c|c|c|c|c|}
\hline No. & Authors & Title & Source & Institute & Study Design & $\begin{array}{l}\text { No. of } \\
\text { Patients }\end{array}$ & Study Aim & $\begin{array}{l}\text { Observation } \\
\text { Period }\end{array}$ \\
\hline 7 & $\begin{array}{l}\text { Bragger U, } \\
\text { Karoussis I, } \\
\text { Persson R, } \\
\text { Pjetursson B, } \\
\text { Salvi G, et al. }\end{array}$ & $\begin{array}{l}\text { Technical and biological } \\
\text { complications/failures } \\
\text { with single crowns and } \\
\text { fixed partial dentures on } \\
\text { implants: a } 10 \text {-year } \\
\text { prospective cohort study. }\end{array}$ & $\begin{array}{l}\text { Clin. Oral Impl. Res. } \\
\text { 2005, 16, 326-334 }\end{array}$ & $\begin{array}{l}\text { Clinic for } \\
\text { Periodontology } \\
\text { and Fixed } \\
\text { Prosthodontics } \\
\text { University of Bern }\end{array}$ & $\begin{array}{l}\text { Prospective } \\
\text { case study }\end{array}$ & 21 & $\begin{array}{l}\text { To assess the incidences of } \\
\text { technical and/or biological } \\
\text { complications and failures } \\
\text { occurring in partially } \\
\text { edentulous patients with } \\
\text { fixed reconstructions on } \\
\text { implants over } 10 \text { years. }\end{array}$ & 120 months \\
\hline 8 & $\begin{array}{l}\text { Cordaro L, } \\
\text { Ercoli C, } \\
\text { Rossini C, } \\
\text { Torsello F, Feng C. }\end{array}$ & $\begin{array}{l}\text { Retrospective evaluation } \\
\text { of complete-arch fixed } \\
\text { partial dentures } \\
\text { connecting teeth and } \\
\text { implant abutments in } \\
\text { patients with normal and } \\
\text { reduced } \\
\text { periodontal support. }\end{array}$ & $\begin{array}{l}\text { J Prosthet Dent 2005, } \\
94,313-320\end{array}$ & $\begin{array}{l}\text { Authors affiliated } \\
\text { with the Eastman } \\
\text { Dental Hospital, } \\
\text { Rome, Italy; } \\
\text { Eastman } \\
\text { Dental Center } \\
\text { Rochester, NY. }\end{array}$ & $\begin{array}{l}\text { Retrospective } \\
\text { case study }\end{array}$ & 20 & $\begin{array}{l}\text { The aim of this retrospective } \\
\text { study was to evaluate the } \\
\text { clinical outcomes of } \\
\text { complete-arch TIFPs in } \\
\text { patients demonstrating } \\
\text { normal or reduced } \\
\text { periodontal support. }\end{array}$ & $\begin{array}{l}24-94 \\
\text { months } \\
\text { average of } \\
36.5 \text { months }\end{array}$ \\
\hline 9 & $\begin{array}{l}\text { Ericsson I, } \\
\text { Lekholm U, } \\
\text { Branemark PI, } \\
\text { Lindhe J, } \\
\text { Glantz PO, et al. }\end{array}$ & $\begin{array}{l}\text { A clinical evaluation of } \\
\text { fixed-bridge restorations } \\
\text { supported by the } \\
\text { combination of teeth and } \\
\text { osseointegrated } \\
\text { titanium implants. }\end{array}$ & $\begin{array}{l}\text { J Clin Periodontol } \\
1986,13,307-312\end{array}$ & $\begin{array}{l}\text { Department of } \\
\text { Periodontology, } \\
\text { University of } \\
\text { Gothenburg, }\end{array}$ & $\begin{array}{l}\text { Prospective } \\
\text { case study }\end{array}$ & 10 & $\begin{array}{l}\text { To investigate whether } \\
\text { titanium fixtures could be } \\
\text { used as combined } \\
\text { abutments with teeth in } \\
\text { fixed bridgework. }\end{array}$ & $\begin{array}{l}6-30 \text { months } \\
\text { average of } \\
17.4 \text { months }\end{array}$ \\
\hline 10 & $\begin{array}{l}\text { Heinemann } \mathrm{F} \text {, } \\
\text { Mundt } \mathrm{T} \text {, Biffar R. }\end{array}$ & $\begin{array}{l}\text { Retrospective evaluation } \\
\text { of temporary cemented, } \\
\text { tooth and implant } \\
\text { supported fixed } \\
\text { partial dentures }\end{array}$ & $\begin{array}{l}\text { Journal of } \\
\text { Cranio-Maxillofacial } \\
\text { Surgery 2006, 34, } \\
\text { Suppl. 2, 86-90 }\end{array}$ & $\begin{array}{l}\text { Private practice } \\
\text { in Germany. }\end{array}$ & $\begin{array}{l}\text { Retrospective } \\
\text { case study }\end{array}$ & 47 & $\begin{array}{l}\text { The aim of this study was to } \\
\text { evaluate TIFPs, and } \\
\text { determine which cement is } \\
\text { best suited for } \\
\text { temporary cementation. }\end{array}$ & 48 months \\
\hline 11 & $\begin{array}{l}\text { Hosny M, Duyck } \\
\text { J, van Steenberghe } \\
\text { D, Naert I. }\end{array}$ & $\begin{array}{l}\text { Within-Subject } \\
\text { Comparison Between } \\
\text { Connected and Non } \\
\text { connected TIFP: Up to } \\
\text { 14-Year Follow-up Study }\end{array}$ & $\begin{array}{l}\text { Int J Prosthodont. } \\
2000,13,340-346 .\end{array}$ & $\begin{array}{l}\text { University } \\
\text { Hospitals of } \\
\text { Catholic, University } \\
\text { of Leuven, Belgium }\end{array}$ & $\begin{array}{l}\text { Retrospective, } \\
\text { case study with } \\
\text { cross-arch } \\
\text { control }\end{array}$ & 18 & $\begin{array}{l}\text { This long-term follow-up } \\
\text { study aimed to compare the } \\
\text { outcome of TIFPs and FSFPs. }\end{array}$ & 168 months \\
\hline 12 & $\begin{array}{l}\text { Kindberg H, } \\
\text { Gunne J, } \\
\text { Kronström M. }\end{array}$ & $\begin{array}{l}\text { Tooth- and } \\
\text { Implant-Supported } \\
\text { Prostheses: } \\
\text { A Retrospective Clinical } \\
\text { Follow-up up to } 8 \text { Years }\end{array}$ & $\begin{array}{l}\text { Int J Prosthodont } \\
2001,14,575-581\end{array}$ & $\begin{array}{l}\text { Department of } \\
\text { Prosthetic Dentistry, } \\
\text { Central Hospital, } \\
\text { Skövde, Sweden }\end{array}$ & $\begin{array}{l}\text { Retrospective } \\
\text { case study }\end{array}$ & 36 & $\begin{array}{l}\text { To evaluate clinical treatment } \\
\text { outcomes of fixed prostheses } \\
\text { in different sizes and with } \\
\text { combinations of different } \\
\text { numbers of teeth and } \\
\text { implants as abutments }\end{array}$ & $\begin{array}{l}14 \text { months to } \\
106 \text { months }\end{array}$ \\
\hline
\end{tabular}


Table 2. Cont

\begin{tabular}{|c|c|c|c|c|c|c|c|c|}
\hline No. & Authors & Title & Source & Institute & Study Design & $\begin{array}{l}\text { No. of } \\
\text { Patients }\end{array}$ & Study Aim & $\begin{array}{l}\text { Observation } \\
\text { Period }\end{array}$ \\
\hline 13 & $\begin{array}{l}\text { KoczorowskiR, } \\
\text { Surdacka A. }\end{array}$ & $\begin{array}{l}\text { Evaluation of bone loss at } \\
\text { single-stage and } \\
\text { two-stage implant } \\
\text { abutments of fixed } \\
\text { partial dentures }\end{array}$ & $\begin{array}{l}\text { Adv Med Sci. 2006, } 51 \\
\text { Suppl. 1, 43-45. }\end{array}$ & $\begin{array}{l}\text { Authors affiliated } \\
\text { with the University } \\
\text { of Medical Sciences } \\
\text { in Poznan }\end{array}$ & $\begin{array}{l}\text { Prospective } \\
\text { case study }\end{array}$ & 32 & $\begin{array}{l}\text { To evaluate alveolar bone } \\
\text { loss at single-stage and } \\
\text { two-stage implants as } \\
\text { abutments of fixed partial } \\
\text { dentures used to replace } \\
\text { missing teeth. }\end{array}$ & $\begin{array}{l}76 \text { implants } \\
\text { reviewed at } \\
24 \text { months, } \\
50 \text { reviewed } \\
\text { up to } \\
72 \text { months }\end{array}$ \\
\hline 14 & $\begin{array}{l}\text { Lindh T, Bäck T, } \\
\text { Nyström E, } \\
\text { Gunne J. }\end{array}$ & $\begin{array}{l}\text { Implant versus } \\
\text { tooth-implant supported } \\
\text { prostheses in the } \\
\text { posterior maxilla: } \\
\text { a 2-year report }\end{array}$ & $\begin{array}{l}\text { Clin. Oral Impl. Res. } \\
\text { 2001, 12, 441-449. }\end{array}$ & $\begin{array}{l}\text { Department of } \\
\text { Prosthetic Dentistry } \\
\text { at Umeå University. }\end{array}$ & $\begin{array}{l}\text { Prospective } \\
\text { clinical study } \\
\text { with } \\
\text { cross-arch control }\end{array}$ & 26 & $\begin{array}{l}\text { To compare the biological } \\
\text { and mechanical } \\
\text { consequences of implants } \\
\text { placed in the posterior } \\
\text { maxilla connected to teeth, or } \\
\text { when used in FSFPs. }\end{array}$ & 24 months \\
\hline 15 & $\begin{array}{l}\text { Lindh T, } \\
\text { Dahlgren S, } \\
\text { Gunnarsson K, } \\
\text { Josefsson T, } \\
\text { Nilson H, et al. }\end{array}$ & $\begin{array}{l}\text { Tooth-Implant Supported } \\
\text { Fixed Prostheses: } \\
\text { A Retrospective } \\
\text { Multicenter Study }\end{array}$ & $\begin{array}{l}\text { Int J Prosthodont } \\
2001,14,321-328 .\end{array}$ & $\begin{array}{l}\text { Multi-centre } \\
\text { (6 centres) }\end{array}$ & $\begin{array}{l}\text { Retrospective } \\
\text { case study }\end{array}$ & 111 & $\begin{array}{l}\text { To investigate the implant } \\
\text { survival rate and loss of } \\
\text { marginal bone, as well as } \\
\text { indications and } \\
\text { complications pertinent to } \\
\text { TIFP treatment. }\end{array}$ & 36 months \\
\hline 16 & $\begin{array}{l}\text { Mundt T, } \\
\text { Hinemann F, } \\
\text { Schankath C, } \\
\text { Schwahn C, } \\
\text { Biffar R. }\end{array}$ & $\begin{array}{l}\text { Retrospective and clinical } \\
\text { evaluation of retrievable, } \\
\text { tooth-implant supported } \\
\text { zirconia-ceramic } \\
\text { restorations }\end{array}$ & $\begin{array}{l}\text { Acta Odontol Scand } \\
2013,71(5), 1326-1334\end{array}$ & $\begin{array}{l}\text { Private practice, } \\
\text { Germany }\end{array}$ & $\begin{array}{l}\text { Retrospective } \\
\text { case study }\end{array}$ & 23 & $\begin{array}{l}\text { To assess retrievable TIFPs } \\
\text { made of veneered zirconia } \\
\text { cores as a viable } \\
\text { treatment option. }\end{array}$ & $\begin{array}{l}12.7-47.9 \\
\text { average of } \\
28.8 \text { months }\end{array}$ \\
\hline 17 & $\begin{array}{l}\text { Naert I, } \\
\text { Quirynen M, } \\
\text { Van Steenberghe D, } \\
\text { Darius P. }\end{array}$ & $\begin{array}{l}\text { A six-year prosthodontic } \\
\text { study of } 509 \\
\text { consecutively inserted } \\
\text { implants for the } \\
\text { treatment of } \\
\text { partial edentulism. }\end{array}$ & $\begin{array}{l}\text { J Prosthet Dent 1992, } \\
67,236-245 .\end{array}$ & $\begin{array}{l}\text { Leuven } \\
\text { University Clinic. }\end{array}$ & $\begin{array}{l}\text { Retrospective } \\
\text { case study }\end{array}$ & $\begin{array}{l}146(80 \\
\text { tooth-to- } \\
\text { implant } \\
\text { bridges })\end{array}$ & $\begin{array}{l}\text { To investigate the connection } \\
\text { between teeth and implants } \\
\text { and its possible harmful } \\
\text { effects on fixture loss and } \\
\text { bone loss as well as to } \\
\text { investigate the use of } \\
\text { composites or porcelain on } \\
\text { the occlusal surfaces } \\
\text { of TIFPs. }\end{array}$ & $\begin{array}{l}2 \text { to } 77 \\
\text { months }\end{array}$ \\
\hline
\end{tabular}


Table 2. Cont

\begin{tabular}{|c|c|c|c|c|c|c|c|c|}
\hline No. & Authors & Title & Source & Institute & Study Design & $\begin{array}{l}\text { No. of } \\
\text { Patients }\end{array}$ & Study Aim & $\begin{array}{l}\text { Observation } \\
\text { Period }\end{array}$ \\
\hline 18 & $\begin{array}{l}\text { Naert I, } \\
\text { Duyck J, Hosny M, } \\
\text { van Steenberghe D. }\end{array}$ & $\begin{array}{l}\text { Freestanding and } \\
\text { tooth-implant connected } \\
\text { prostheses in the } \\
\text { treatment of partially } \\
\text { edentulous patients } \\
\text { Part I: An up to } 15 \text {-years } \\
\text { clinical evaluation. }\end{array}$ & $\begin{array}{l}\text { Clin. Oral Impl. Res. } \\
\text { 2001, 12, 237-244 }\end{array}$ & $\begin{array}{l}\text { Dept. of } \\
\text { Periodontology and } \\
\text { of Prosthetic } \\
\text { Dentistry at the } \\
\text { Hospitals of the } \\
\text { Catholic University } \\
\text { of Leuven. }\end{array}$ & $\begin{array}{l}\text { Retrospective } \\
\text { case study with } \\
\text { cross-arch } \\
\text { control }\end{array}$ & 123 & $\begin{array}{l}\text { To compare TIFP and FSFP } \\
\text { treatment modalities with } \\
\text { each other based on implant, } \\
\text { tooth and prosthesis } \\
\text { complications. }\end{array}$ & $\begin{array}{l}\text { 18-180 } \\
\text { months }\end{array}$ \\
\hline 19 & $\begin{array}{l}\text { Nickenig HJ, } \\
\text { Schafer C, } \\
\text { Spiekermann H. }\end{array}$ & $\begin{array}{l}\text { Survival and } \\
\text { complication rates of } \\
\text { combined } \\
\text { tooth-implant-supported } \\
\text { fixed partial dentures }\end{array}$ & $\begin{array}{l}\text { Clin. Oral Impl. Res. } \\
2006,17,506-511\end{array}$ & $\begin{array}{l}\text { Based on the } \\
\text { treatment } \\
\text { documentations of } \\
\text { a Bundeswehr } \\
\text { dental clinic } \\
\text { (Cologne-Wahn } \\
\text { German Air } \\
\text { Force Garrison) }\end{array}$ & $\begin{array}{l}\text { Retrospective } \\
\text { case study }\end{array}$ & 83 patients & $\begin{array}{l}\text { To review the incidence of } \\
\text { biological and technical } \\
\text { complications in case of TIFP } \\
\text { treatment on the basis of } \\
\text { survival data regarding } \\
\text { clinical cases. }\end{array}$ & $\begin{array}{l}26.4-99.6 \\
\text { average of } \\
56.8 \text { months. }\end{array}$ \\
\hline 20 & $\begin{array}{l}\text { Noda K, } \\
\text { Arakawa H, } \\
\text { Maekawa K, } \\
\text { Hara ES, } \\
\text { Yamazaki S. }\end{array}$ & $\begin{array}{l}\text { Identification of risk } \\
\text { factors for fracture of } \\
\text { veneering materials and } \\
\text { screw loosening of } \\
\text { implant-supported fixed } \\
\text { partial dentures in } \\
\text { partially edentulous cases }\end{array}$ & $\begin{array}{l}\text { Journal of Oral } \\
\text { Rehabilitation 2013, } \\
40,214-220\end{array}$ & $\begin{array}{l}\text { Fixed Prosthodontic } \\
\text { Clinic of Okayama } \\
\text { University Dental } \\
\text { Hospital, } \\
\text { Okayama, Japan }\end{array}$ & $\begin{array}{l}\text { Retrospective } \\
\text { case study }\end{array}$ & $\begin{array}{l}120 \text { for } \\
\text { veneer } \\
\text { fracture, } \\
81 \text { for } \\
\text { abutment } \\
\text { screw } \\
\text { loosening. }\end{array}$ & $\begin{array}{l}\text { To identify the risk factors for } \\
\text { fracture of veneering } \\
\text { materials and screw } \\
\text { loosening of } \\
\text { implant-supported fixed } \\
\text { partial dentures in partially } \\
\text { edentulous cases. }\end{array}$ & $\begin{array}{l}\text { Average of } \\
48 \text { months } \\
\text { for screw } \\
\text { loosening } \\
\text { group and } \\
30 \text { months } \\
\text { for veneer } \\
\text { fracture } \\
\text { group. }\end{array}$ \\
\hline 21 & $\begin{array}{l}\text { Özkan Y, } \\
\text { Akoğlu B, } \\
\text { Kulak-Özkan Y. }\end{array}$ & $\begin{array}{l}\text { Five-year Treatment } \\
\text { Outcomes with Four } \\
\text { Types of Implants in the } \\
\text { Posterior Maxilla and } \\
\text { Mandible in Partially } \\
\text { Edentulous Patients: } \\
\text { A Retrospective Study }\end{array}$ & $\begin{array}{l}\text { Int J Oral Maxillofac } \\
\text { Implants 2011, 26, } \\
639-647\end{array}$ & $\begin{array}{l}\text { University of } \\
\text { Marmara, } \\
\text { Department of Oral } \\
\text { Surgery and } \\
\text { Depart-ment of } \\
\text { Prosthetic Dentistry, } \\
\text { Istanbul, Turkey, }\end{array}$ & $\begin{array}{l}\text { Retrospective } \\
\text { case study }\end{array}$ & 83 & $\begin{array}{l}\text { To evaluate the clinical and } \\
\text { radiologic outcomes of four } \\
\text { types of implants and their } \\
\text { suprastructures in the } \\
\text { posterior maxilla and } \\
\text { mandible in partially } \\
\text { edentulous patients after } \\
5 \text { years of functional loading. }\end{array}$ & 60 months \\
\hline
\end{tabular}


Table 2. Cont.

\begin{tabular}{|c|c|c|c|c|c|c|c|c|}
\hline No. & Authors & Title & Source & Institute & Study Design & $\begin{array}{l}\text { No. of } \\
\text { Patients }\end{array}$ & Study Aim & $\begin{array}{l}\text { Observation } \\
\text { Period }\end{array}$ \\
\hline 22 & $\begin{array}{l}\text { Palmer RM, } \\
\text { Howe LC, } \\
\text { Palmer PJ. }\end{array}$ & $\begin{array}{l}\text { A prospective 3-year } \\
\text { study of fixed bridges } \\
\text { linking Astra Tech ST } \\
\text { implants to natural teeth }\end{array}$ & $\begin{array}{l}\text { Clin. Oral Impl. Res. } \\
\text { 2005, 16, 302-307 }\end{array}$ & $\begin{array}{l}\text { Authors affiliation: } \\
\text { Departments of } \\
\text { Perio. and Prosth. } \\
\text { GKT Dental } \\
\text { Institute, King's } \\
\text { College, London. }\end{array}$ & $\begin{array}{l}\text { Prospective } \\
\text { case study }\end{array}$ & 19 & $\begin{array}{l}\text { To assess the clinical and } \\
\text { radiographic performance of } \\
\text { the teeth and implants used } \\
\text { to support three-unit fixed } \\
\text { bridges subjected to normal } \\
\text { functional loads. }\end{array}$ & 36 months \\
\hline 23 & $\begin{array}{l}\text { Rammelsberg P, } \\
\text { Schwarz S, } \\
\text { Schroeder C, } \\
\text { Bermejo J, } \\
\text { Gabbert O. }\end{array}$ & $\begin{array}{l}\text { Short-term complications } \\
\text { of implant-supported } \\
\text { and combined } \\
\text { tooth-implant-supported } \\
\text { fixed dental prostheses }\end{array}$ & $\begin{array}{l}\text { Clin. Oral Impl. Res. } \\
\text { 2013, 24, 758-762 }\end{array}$ & $\begin{array}{l}\text { Department of } \\
\text { Prosthodontics at } \\
\text { the University } \\
\text { Hospital of } \\
\text { Heidelberg. }\end{array}$ & $\begin{array}{l}\text { Retrospective } \\
\text { case study }\end{array}$ & 132 & $\begin{array}{l}\text { To investigate the } \\
\text { complications of } \\
\text { metal-ceramic and } \\
\text { all-ceramic FDPs supported } \\
\text { by implants or by a } \\
\text { combination of teeth } \\
\text { and implants. }\end{array}$ & $\begin{array}{l}\text { Average of } \\
28 \text { months. }\end{array}$ \\
\hline 24 & $\begin{array}{l}\text { Romeo E, Lops D, } \\
\text { Margutti E, } \\
\text { Ghisolfi M, } \\
\text { Chiapasco M, } \\
\text { et al. }\end{array}$ & $\begin{array}{l}\text { Long-term Survival and } \\
\text { Success of Oral Implants } \\
\text { in the Treatment of Full } \\
\text { and Partial Arches: A } \\
\text { 7-year Prospective Study } \\
\text { with the ITI Dental } \\
\text { Implant System }\end{array}$ & $\begin{array}{l}\text { Int J Oral Maxillofac } \\
\text { Implants 2004, 19, } \\
\text { 247-259 }\end{array}$ & $\begin{array}{l}\text { Dental Clinic, } \\
\text { Department of } \\
\text { Medicine Surgery } \\
\text { and Medicine, } \\
\text { University of } \\
\text { Milan, Italy. }\end{array}$ & $\begin{array}{l}\text { Prospective } \\
\text { case study }\end{array}$ & 201 & $\begin{array}{l}\text { To evaluate the medium- to } \\
\text { long-term survival and } \\
\text { success of different } \\
\text { implant-supported } \\
\text { prostheses supported by ITI } \\
\text { implants and to determine } \\
\text { whether significant } \\
\text { differences in survival and } \\
\text { success could be observed for } \\
\text { different implant } \\
\text { placement sites. }\end{array}$ & 46.2 months \\
\hline 25 & $\begin{array}{l}\text { Tangerud T, } \\
\text { Grønningsæter } \\
\text { AG, Taylor A. }\end{array}$ & $\begin{array}{l}\text { Fixed Partial Dentures } \\
\text { Supported by Natural } \\
\text { Teeth and Brånemark } \\
\text { System Implants: } \\
\text { A 3-year Report }\end{array}$ & $\begin{array}{l}\text { Int J Oral Maxillofac } \\
\text { Implants 2002, 17, } \\
212-219\end{array}$ & $\begin{array}{l}\text { Dental School, } \\
\text { University of } \\
\text { Bergen, Norway }\end{array}$ & $\begin{array}{l}\text { Prospective } \\
\text { case study }\end{array}$ & 30 & $\begin{array}{l}\text { To evaluate TIFPs in a variety } \\
\text { of clinical situations. }\end{array}$ & 36 months \\
\hline
\end{tabular}




\section{Results}

Twenty-five texts studying combined TIFPs in 22 different patient cohorts were selected for analysis. The majority of studies dealt with a mixture of short- and long-span bridges. However, nine dealt with solely short-span restorations ( $<5$ units) and one dealt only with long-span bridges ( $>5$ units). Twenty-one of the studies were carried out in institutions such as dental hospitals, dental schools, and specialized clinics, another two were multi-center studies, and two were carried out in private clinics. The studies were carried out by specialists, university professors, and general dental practitioners. Of the selected texts, 13 described prospective cohort studies (four of which followed one patient cohort) and another 12 described retrospective cohort studies. Five studies used cross-arch controls, two of which had the treatment assigned to each side randomly. In six studies, the TIFP treatment was assessed against a group of FSFPs. The studies dealt with commercially available implant systems and were carried out over an observational period of at least 2 years, and up to 15 years in one study. In five of the studies, some patients were observed for less than 1 year.

The results of this review are divided into two groups: one dealing with complications and the other dealing with survival rates. Complications relating to tooth and implant rehabilitation are further divided into three sections. One section describes complications associated with the implants, another section describes complications associated with the abutment teeth, and the third section describes complications associated with the restoration itself. Similarly, all the studies that gave data on overall survival and complication-free survival are included in the survival section (Figure 2).

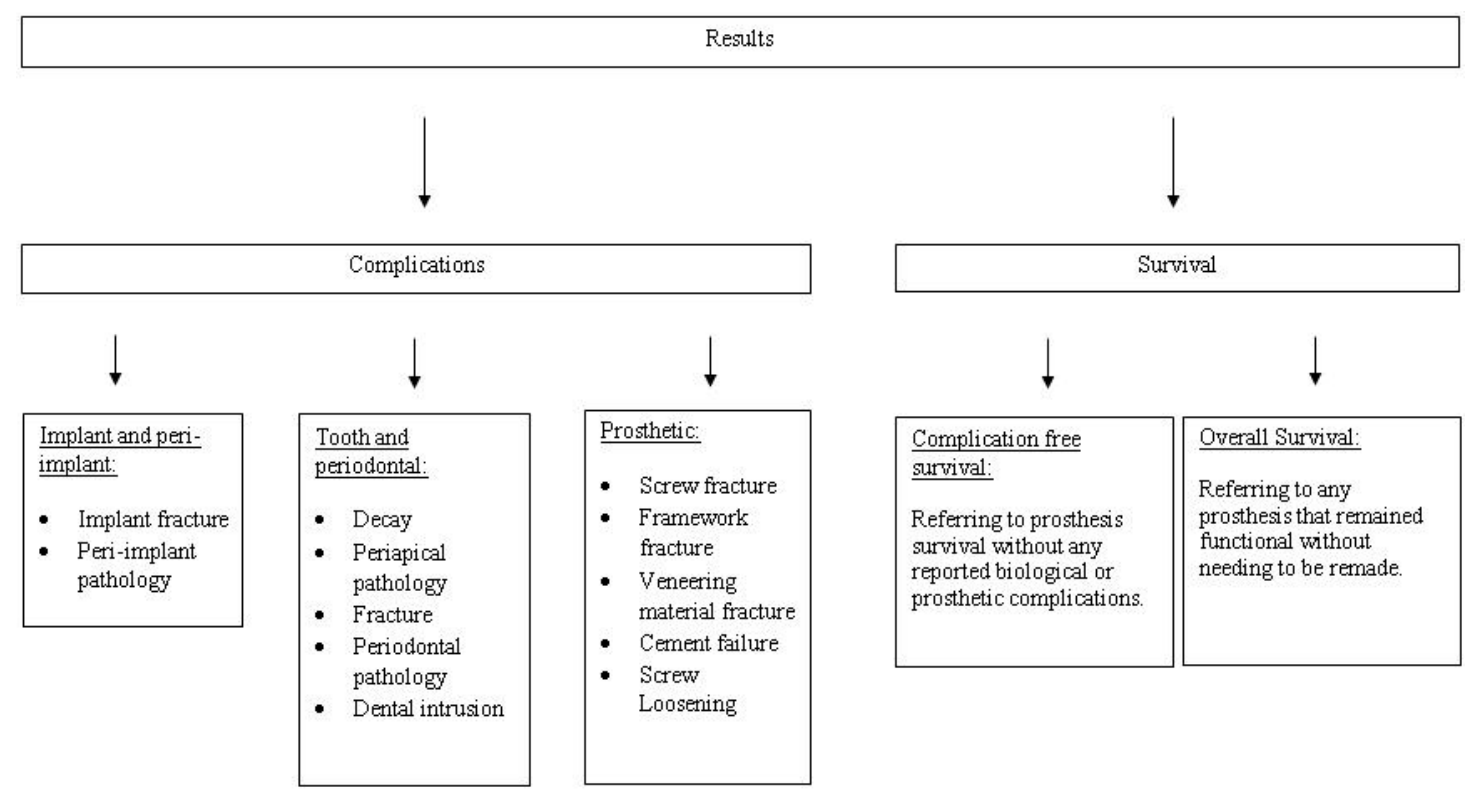

Figure 2. A flow diagram of outcomes assessed in this analysis.

\subsection{Complications}

\subsubsection{Implant and Peri-Implant Complications}

Of the 25 selected studies, 23 went into detail on implant related complications in TIFPs (Table 3). The reviewed studies dealt with at least thirteen different implant brands placed both in the maxilla and mandible supporting short- and long-span TIFPs made out of veneered metal. In one study, veneered zirconia bridges were used. The implants supported a mixture of rigid and non-rigid constructions that were either screw-retained or cemented via temporary, semi-permanent or permanent cements onto the implants. Out of a total of 1610 implants connected to teeth, 40 implants were lost over observation periods that ranged from 6 to 180 months. The majority of implants lost were as a result of a loss of 
integration, either due to peri-implant disease or primary biological complications that eventually resulted in mobility $(n=33)$. The remaining implant losses occurred due to fracture $(n=7)$ (Table 4$)$.

Twenty-one of the studies reviewed also went into detail on peri-implant bone changes, which are summarized in Table 3. In some of the studies reviewed, significantly more bone loss was observed around implants supporting FSFPs than those supporting TIFPs $[9,29,40]$. Similarly, a study by Palmer et al., which made use of 19 implants, connected to teeth in three-unit TIFPs, in Kennedy Class II cases, showed no significant bone loss around implants connected to teeth but instead noted 10 cases where there was a gain in peri-implant bone levels. In the other nine implants, bone loss of up to $1.2 \mathrm{~mm}$ was detected over 36 months [8]. Four texts [41-44] following the same cohort of 23 patients over 10 years also found less bone loss around TIFP implants than around FSFP implants. Significantly less bone loss was detected at the 2nd and 10th year around implants connected to teeth than around the implants in the cross-arch control group [41,44]. In this study, marginal bone loss was minimal, with $0.5-0.7 \mathrm{~mm}$ lost over 10 years in connected implants.

Unlike the above mentioned studies, in a retrospective study by Naert et al. including 339 tooth connected implants, there were no statistically different bone level changes from 0 to 6 months between the implants supporting FSFPs and those supporting non-rigid and rigid TIFPs. There was also no statistical difference in bone loss from 6 months to 15 years between the free-standing group $(0.02 \mathrm{~mm} /$ year $)$ and the non-rigid group $(0.04 \mathrm{~mm} /$ year $)$. There was, however, a statistically significant difference between the rigid group $(0.09 \mathrm{~mm} /$ year $)$ and the free-standing group $(p=0.004)$ [30]. In another retrospective study by Naert et al., thirty-one implants were connected non-rigidly, and 41 were connected rigidly to teeth; no statistical difference was detected between bone loss around distal implant in FSFP and TIFP cases [46]. Rigid and non-rigid bridge constructions were also assessed in a study by Block et al., which compared three-unit, non-rigid and rigid TIFPs. Four implants developed bone loss greater than $2 \mathrm{~mm}$ over 60 months. In this study, there was no significant difference in bone loss around rigidly and non-rigidly connected implants, with an average of $0.91 \mathrm{~mm}$ of bone loss over the 5-year study period [31]. Similarly, in a study involving 41 implants in long-span rigid and non-rigid cases, bone loss of less than $1 \mathrm{~mm}$ was reported in all connected implants, except in two patients where three fixtures demonstrated bone loss exceeding $1 \mathrm{~mm}$ but no more than $3 \mathrm{~mm}$ [7].

Long-span bridges ( $>5$ units) were also studied in another retrospective study involving 112 implants that were rigidly or non-rigidly connected to teeth. In this study, 46 implants showed marginal bone loss after a year, 31 of which had up to one thread, 11 had up to two threads, 2 had up to three threads, and 2 had up to four threads of bone loss. Over the next four years, the progression of marginal bone loss was minimal. In this study, six implants were lost due to loss of integration [47]. A retrospective study by Cordaro et al. also followed long-span TIFPs rigidly and non-rigidly connecting implants to teeth with healthy and compromised periodontal ligaments. This study gave more positive results, with 87 out of 90 implants showing stable bone levels during the observation period while 3 had bone loss greater than $2 \mathrm{~mm}$ [34].

A study by Koczorowski and Surdacka comparing bone loss for 76 posterior implants placed in one or two stage procedures supporting TIFPs also gave positive results, with values for marginal bone loss in line with guidelines set by Albrektsson for implant success [48]. The mean bone loss at the implants after 2 years of using fixed partial dentures supported on mixed abutments was $0.70 \mathrm{~mm} \pm 0.50$ and $1.73 \mathrm{~mm} \pm 0.41$ after 6 years. This study showed no significant difference in marginal bone loss around implants placed in one or two stage procedures and connected to teeth [49]. On the other hand, in another study, 185 implants were connected to 220 teeth in six centers and described by Lindh et al. Seventy-four implants were followed for 3 years during which there was a statistically significant loss of bone over the first year in both jaws $(p<0.01)$ (maxilla: $0.33 \mathrm{~mm}$, standard deviation (SD) $0.56 \mathrm{~mm}$; mandible: $0.36 \mathrm{~mm}$, SD $0.49 \mathrm{~mm}$ ), with 9 out of the 74 implants losing more than $1 \mathrm{~mm}$ of marginal bone during the first year. Changes in marginal bone level during the second and third years did not reach significant levels $(n=9: 0.3 \mathrm{~mm}, \mathrm{SD} 0.9 \mathrm{~mm} ; n=65: 0.1 \mathrm{~mm}$, SD $0.5 \mathrm{~mm})$ [50]. 
A long-term study by Bragger et al. followed partially edentulous patients restored with SCs, FSFPs, and TIFPs over 10 years. Twenty-one patients had 22 implants rigidly connected to teeth supporting 22 TIFPs. Although no measurements for bone loss were given, three implants were reported lost, and a further three implants needed treatment for peri-implantitis. Statistically significantly fewer biological failures occurred with FSFPs compared to TIFPs (P 1/4 0.022) [51]. Comparisons can be drawn with the study by Naert et al., where rigidly connected implants demonstrated significantly more bone loss than implants supporting FSFPs. Similarly, in a prospective study by Tangerud et al., 85 abutments were rigidly connected to teeth through longand short-span bridges. Two of these implants were lost after prosthetic loading, and a bone reduction of $0.8 \mathrm{~mm} \pm 1.1 \mathrm{~mm}$ was detected around implants from the time of loading to the 3-year review [52].

A study by Ozkan et al. also examined implants supporting SCs, FSFPs, and TIFPs. Following loading, the nine implants connected to teeth met the success criteria for mobility, and all implants were surrounded by stable healthy tissue with good hygiene. There were no significant differences in crestal bone level changes between TIFP and FSFP implants [53]. Likewise, Romeo et al. studied the performance of implants supporting SCs, TIFPs, and FSFPs. Although no measurements for marginal bone loss were given, it is worth noting that, in this prospective study, 13 TIFPs were supported by 31 implants of which $90.6 \%$ survived, compared to $96.1 \%$ for FSFPs. Implant success was $70.6 \%$ for TIFPs, compared to $73.8 \%$ for implants supporting FSFPs. Survival rates for implants supporting TIFPs and FSFPs were similar [54].

One study by Nickenig et al. retrospectively analyzed 142 implants connected to 132 abutment teeth in 84 TIFP implants (rigid $n=56$, non-rigid $n=28$ ), of which $40 \%$ were three-unit, and $33 \%$ were of five or more units. In this study, no implants needed to be removed, and less than $1 \%$ had probing depths of more than $5 \mathrm{~mm}$ after 5 years [35].

\subsubsection{Natural Tooth and Periodontal Complications}

Nineteen of the 25 studies selected for this review went into detail about the condition of the natural tooth abutment supporting TIFPs (Table 5). In these studies, teeth were either rigidly or non-rigidly connected to implants via long- or short-span bridges. In all but one study, teeth were permanently or temporarily cemented to the prostheses either directly or indirectly through a coping; otherwise, the prosthesis was left uncemented with the tooth functioning as a telescopic abutment for the prosthesis. In one study, the prostheses were not cemented, but instead screwed onto a coping fabricated with a thread.

The selected studies used teeth with healthy periodontia showing varying degrees of bone loss around them. In none of the studies did the teeth show more than physiological mobility. Two studies used only vital teeth as abutments, seven studies used both RCT and vital teeth, and the other nine studies failed to give information on the endodontic status of the abutment teeth prior to treatment. The RCT teeth were restored with post and cores. In the studies reviewed, 38 out of a total of 1301 teeth were lost over observation periods, varying from 6 to 180 months. Of the 16 teeth lost to fracture, at least 6 were previously RCT. Unfortunately, of the studies that observed tooth fracture, only two specified whether the fractured teeth were previously RCT [31,52], and it is not known if the other 10 fractured teeth were also RCT. Of the 1301 teeth reviewed, 73 teeth intruded, 35 of which were detected in one study that used photographs to assess intrusion. Of the 73 intrusions, 51 occurred in non-rigidly connected teeth, 8 in rigid bridges with failure of the cement or breakage/loosening of the connector locking screw, and 14 were observed in rigidly connected teeth with no documented failure of the cement. In some of these 14 cases, temporary cement was used to fix the prosthesis to the natural abutment. 
Table 3. Table of studies detailing failures of implants supporting TIFPs.

\begin{tabular}{|c|c|c|c|c|c|c|}
\hline Author/Year & Methodology & Implant Brand & $\begin{array}{l}\text { Number of } \\
\text { Connected } \\
\text { Implants }\end{array}$ & $\begin{array}{l}\text { Connected } \\
\text { Implants } \\
\text { Lost }\end{array}$ & Peri-Implant Bone Changes & $\begin{array}{l}\text { Observation } \\
\text { Period }\end{array}$ \\
\hline (Akca and Cehreli 2008) & $\begin{array}{l}\text { Prospective study comparing TIFPs } \\
\text { and FSFPs. }\end{array}$ & ITI/Straumann & 34 & 0 & $\begin{array}{l}+0.19 \mathrm{~mm}( \pm 0.52 \mathrm{~mm}) \text { change in bone level which } \\
\text { was significantly less bone loss than in FSFPs. }\end{array}$ & $\begin{array}{l}\text { 24-30 months } \\
\text { (mean } 26 \text { months) }\end{array}$ \\
\hline $\begin{array}{l}\text { (Astrand } \text { et al. 1991, } \\
\text { Gunne } \text { et al. 1992, } \\
\text { Olsson } \text { et al. 1995, } \\
\text { Gunne } \text { et al. 1999) }\end{array}$ & $\begin{array}{l}\text { Prospective study comparing TIFPs } \\
\text { and FSFPs, randomized cross-arch } \\
\text { control studt. }\end{array}$ & Nobel Biocare & 23 & 2 & $\begin{array}{l}-0.5-0.7 \mathrm{~mm} \text { over } 10 \text { years not statistically } \\
\text { significant to the contralateral side supporting } \\
\text { FSFP implants. }\end{array}$ & 120 months \\
\hline (Block et al. 2002) & $\begin{array}{l}\text { Prospective study comparing rigid } \\
\text { and non-rigid TIFPs, randomized } \\
\text { cross-arch study. }\end{array}$ & Omniloc & 60 & 1 & $\begin{array}{l}0.91 \mathrm{~mm} \text { Average bone loss. No significant } \\
\text { difference in bone loss around rigidly and } \\
\text { non-rigidly connected implants. Four implants } \\
\text { developed bone loss }>2 \mathrm{~mm} \text {. }\end{array}$ & 60 months \\
\hline (Bragger et al. 2005) & $\begin{array}{l}\text { Prospective study following single } \\
\text { crown, FSFP and TIFP restorations. }\end{array}$ & ITI/Straumann & 22 & 3 & Three implants lost due to excessive bone loss. & 120 months \\
\hline (Cordaro et al. 2005) & $\begin{array}{l}\text { Retrospective study analyzing the } \\
\text { performance of full-arch TIFPs. }\end{array}$ & $\begin{array}{l}\text { 3i Implant and } \\
\text { ITI/Straumann }\end{array}$ & 90 & 1 & $\begin{array}{l}87 \text { implants had stable bone levels during the } \\
\text { observation period while } 3 \text { had bone loss than } \\
>2 \mathrm{~mm} \text {. }\end{array}$ & $\begin{array}{l}\text { 24-94 months } \\
\text { (mean } 36.5 \text { months) }\end{array}$ \\
\hline (Ericsson et al. 1986) & $\begin{array}{l}\text { Prospective study following } \\
\text { implants rigidly and non-rigidly } \\
\text { connected to teeth. }\end{array}$ & Branemark & 41 & 0 & $\begin{array}{l}<1 \mathrm{~mm} \text { marginal bone loss round most implants; } \\
1-3 \mathrm{~mm} \text { bone loss around } 3 \text { fixtures and }>3 \mathrm{~mm} \\
\text { bone loss around } 2 \text { implants in one patient and with } \\
\text { rigid connection. }\end{array}$ & $\begin{array}{l}6-30 \text { months (mean } \\
17.4 \text { months) }\end{array}$ \\
\hline (Heinemann et al. 2006) & $\begin{array}{l}\text { Retrospective evaluation of different } \\
\text { temporary cements in TIFP cases. }\end{array}$ & Tiolox & 155 & 1 & $\begin{array}{l}\text { Two implants developed peri-implantitis of which } \\
\text { one was lost. }\end{array}$ & 48 months \\
\hline (Hosny et al. 2000) & $\begin{array}{l}\text { Retrospective study of TIFPs with } \\
\text { cross-arch FSFP control. }\end{array}$ & Branemark & 30 & 0 & $\begin{array}{l}1.9 \mathrm{~mm} \text { : Average bone loss over } 15 \text { years } \\
(2.2 \mathrm{~mm} / \text { year for the first } 6 \text { months, } 0.015 \mathrm{~mm} / \text { year } \\
\text { thereafter); More bone loss in FSFP group; however, } \\
\text { difference not significant. }\end{array}$ & $\begin{array}{l}\text { 15-168 months } \\
\text { (mean } 78 \text { months) }\end{array}$ \\
\hline (Kindberg et al. 2001) & $\begin{array}{l}\text { Retrospective analysis of implants } \\
\text { rigidly or non-rigidly connected } \\
\text { to teeth. }\end{array}$ & Nobel Biocare & 112 & 6 & $\begin{array}{l}\text { After } 1 \text { year, } 46 \text { implants showed marginal bone } \\
\text { loss, } 31 \text { up to one thread, } 11 \text { up to two threads, } 2 \text { up } \\
\text { to three threads and } 2 \text { up to four threads, for the } \\
\text { three and five year examination progression of } \\
\text { bone loss was minimal. }\end{array}$ & $\begin{array}{l}\text { 14-107 months } \\
\text { (mean } 58.3 \text { months) }\end{array}$ \\
\hline $\begin{array}{l}\text { (Koczorowski and } \\
\text { Surdacka 2006) }\end{array}$ & $\begin{array}{l}\text { Prospective evaluation of posterior } \\
\text { implants connected to teeth. }\end{array}$ & Osteoplant & 76 & 0 & $\begin{array}{l}-0.70 \mathrm{~mm} \pm 0.50 \text { after two years and }-1.73 \mathrm{~mm} \\
\pm 0.41 \text { after six years of mean marginal bone loss. }\end{array}$ & $\begin{array}{l}24-72 \text { months } \\
\text { (mean } 43 \text { months) }\end{array}$ \\
\hline
\end{tabular}


Table 3. Cont.

\begin{tabular}{|c|c|c|c|c|c|c|}
\hline Author/Year & Methodology & Implant Brand & $\begin{array}{l}\text { Number of } \\
\text { Connected } \\
\text { Implants }\end{array}$ & $\begin{array}{l}\text { Connected } \\
\text { Implants } \\
\text { Lost }\end{array}$ & Peri-Implant Bone Changes & $\begin{array}{l}\text { Observation } \\
\text { Period }\end{array}$ \\
\hline (Lindh et al. 2001a) & $\begin{array}{l}\text { Prospective study of TIFPs with } \\
\text { cross-arch control FSFPs in Kennedy } \\
\text { Class I patients. }\end{array}$ & Nobel Biocare & 26 & 1 & $\begin{array}{l}-0.09 \pm 0.52 \mathrm{~mm} \text { around the posterior connected } \\
\text { implant. The difference in bone loss from loading to } \\
24 \text { months was significant for posterior implant in } \\
\text { FSFPs but not significant for posterior implants } \\
\text { in TISP. }\end{array}$ & 24 months \\
\hline (Lindh et al. 2001b) & $\begin{array}{l}\text { Multi-centre retrospective study } \\
\text { following TIFPs. }\end{array}$ & $\begin{array}{l}\text { Nobel Biocare and } \\
\text { Straumann }\end{array}$ & 185 & 5 & $\begin{array}{l}1.7 \mathrm{~mm}, \mathrm{SD} 0.8 \mathrm{~mm} \text { bone loss at } 12 \text { months in } 9 \text { of } \\
\text { the } 74 \text { implants reviewed for the whole } 3 \text { years, } \\
0.3 \mathrm{~mm} \text {, SD } 0.7 \text { many more bone loss in the other } \\
65 \text { implants. The subsequent loss of marginal bone } \\
\text { during the second and third years for these two } \\
\text { groups of implants was lower ( } n=9: 0.3 \mathrm{~mm} \text {, SD } \\
0.9 \mathrm{~mm} ; n=65: 0.1 \mathrm{~mm} \text {, SD } 0.5 \text { many more). }\end{array}$ & 36 months \\
\hline (Mundt et al. 2013) & $\begin{array}{l}\text { Retrospective study assessing } \\
\text { zirconia TIFPs. }\end{array}$ & $\begin{array}{l}38 \text { Tiolox, } 8 \text { Ankylos, } \\
5 \text { Straumann }\end{array}$ & 51 & 0 & $\begin{array}{l}\text { No marginal bone loss measurements however, by } \\
\text { the end of the examination period only one implant } \\
\text { had bleeding on probing. }\end{array}$ & $\begin{array}{l}\text { 12.7-47.9 months } \\
\text { (mean: } 28.8 \text { months) }\end{array}$ \\
\hline (Naert et al. 1992) & $\begin{array}{l}\text { Retrospective analysis of FSFPs } \\
\text { and TIFPs. }\end{array}$ & Branemark & 80 & 5 & $\begin{array}{l}1.02 \mathrm{~mm} \text { mean bone loss in Year } 1 \text { followed by } 0.10 \\
\mathrm{~mm} \text { bone gain in year two. No statistical difference } \\
\text { between bone loss around the ditstal implant in } \\
\text { connected and non-connected cases. }\end{array}$ & 72 months \\
\hline (Naert et al. 2001) & $\begin{array}{l}\text { Retrospective analysis of TIFPs } \\
\text { compared to a control group of } \\
\text { similar FSFPs. }\end{array}$ & Branemark & 339 & 10 & $\begin{array}{l}\text { No statistical difference from } 0 \text { to } 6 \text { months } \\
\text { between FS, non-rigid and rigid group, there was } \\
\text { no statistical difference in bone loss from } 6 \text { to } 180 \\
\text { years between the FSFP group } 0.02 \mathrm{~mm} \text { a year and } \\
\text { non-rigid group } 0.04 \mathrm{~mm} \text { a year. There was, } \\
\text { however, a statistical significant difference between } \\
\text { the rigid group } 0.09 \mathrm{~mm} \text { a year and the FSFP group } \\
(p=0.004) \text {. }\end{array}$ & $\begin{array}{l}18-180 \text { months } \\
\text { (mean } 78 \text { months) }\end{array}$ \\
\hline (Nickenig et al. 2006) & $\begin{array}{l}\text { Retrospective analysis of implants } \\
\text { rigidly and non-rigidly connected } \\
\text { to teeth. }\end{array}$ & $\begin{array}{l}85 \% \text { Branemark and } \\
\text { Straumann; } 15 \% \\
\text { including Replace, } \\
\text { Friadent, Ankylos } \\
\text { and others }\end{array}$ & 142 & 0 & $\begin{array}{l}5 \mathrm{~mm} \text { probing depths were found in }<1 \% \text { of } \\
\text { implants after } 5 \text { years. }\end{array}$ & $\begin{array}{l}26-100 \text { months } \\
\text { (mean } 56.8 \text { months) }\end{array}$ \\
\hline (Ozkan et al. 2011) & $\begin{array}{l}\text { A retrospective study of single } \\
\text { implant crowns, TIFPs and FSFPs. }\end{array}$ & $\begin{array}{l}\text { Straumann, swiss } \\
\text { plus, camlog, } \\
\text { Friadent. }\end{array}$ & 9 & 0 & $\begin{array}{l}\text { All implants met the criteria for success. All } \\
\text { implants were surrounded by stable healthy tissue } \\
\text { with crestal bone level changes not significantly } \\
\text { different between TIFP and FSFP implants. }\end{array}$ & 60 months \\
\hline
\end{tabular}


Table 3. Cont.

\begin{tabular}{|c|c|c|c|c|c|c|}
\hline Author/Year & Methodology & Implant Brand & $\begin{array}{l}\text { Number of } \\
\text { Connected } \\
\text { Implants }\end{array}$ & $\begin{array}{l}\text { Connected } \\
\text { Implants } \\
\text { Lost }\end{array}$ & Peri-Implant Bone Changes & $\begin{array}{l}\text { Observation } \\
\text { Period }\end{array}$ \\
\hline (Palmer et al. 2005) & $\begin{array}{l}\text { A prospective study of rigidly } \\
\text { connected teeth and implants via } \\
\text { short-span bridges in Kennedy } \\
\text { Class II cases }\end{array}$ & Astra tech & 19 & 0 & $\begin{array}{l}\text { Up to } 1.2 \mathrm{~mm} \text { of bone loss seen in } 9 \text { patients; } \\
10 \text { patients experienced no change or an increase in } \\
\text { bone level around connected implants. }\end{array}$ & 36 months \\
\hline (Romeo et al. 2004) & $\begin{array}{l}\text { A prospective study of various types } \\
\text { of implant-supported } \\
\text { prostheses designs. }\end{array}$ & ITI & 31 & 3 & $\mathrm{~N} / \mathrm{A}$ & $\begin{array}{l}\text { 16-84 months } \\
\text { (mean } 46.2 \text { months) }\end{array}$ \\
\hline (Tangerud et al. 2002) & $\begin{array}{l}\text { Prospective study monitoring } \\
30 \text { rigid TIFPs. }\end{array}$ & Branemark & 85 & 2 & $\begin{array}{l}\text { Bone loss of } 0.8 \mathrm{~mm} \pm 1.1 \mathrm{~mm} \text { around connected } \\
\text { implants from time of loading to } 3 \text { years review. }\end{array}$ & 36 months \\
\hline
\end{tabular}

Table 4. Table of failed implants.

\begin{tabular}{|c|c|c|c|c|c|c|c|c|}
\hline Author/Year & $\begin{array}{c}\text { Location of } \\
\text { Failed Implant }\end{array}$ & $\begin{array}{l}\text { Opposing } \\
\text { Dentition }\end{array}$ & $\begin{array}{l}\text { Connection } \\
\text { Type }\end{array}$ & $\begin{array}{l}\text { Reconstruction } \\
\text { Length }\end{array}$ & FPD Retention & $\begin{array}{l}\text { Time after } \\
\text { Loading }\end{array}$ & Implant Brand & Reason for Failure \\
\hline \multirow[t]{2}{*}{$\begin{array}{l}\text { (Astrand } \text { et al., 1991, } \\
\text { Gunne } \text { et al., 1992, } \\
\text { Olsson } \text { et al., 1995, } \\
\text { Gunne } \text { et al., 1999) }\end{array}$} & $\begin{array}{l}\text { Posterior } \\
\text { mandible }\end{array}$ & $\begin{array}{l}\text { Complete } \\
\text { Removable }\end{array}$ & Rigid & 3-unit & Screw & $\begin{array}{l}\text { Within } \\
18 \text { months }\end{array}$ & Nobel Biocare & Loss of integration \\
\hline & $\begin{array}{l}\text { Posterior } \\
\text { mandible }\end{array}$ & $\begin{array}{l}\text { Complete } \\
\text { Removable }\end{array}$ & Rigid & 3-unit & Screw & $\begin{array}{c}\text { Within } \\
18 \text { months }\end{array}$ & Nobel Biocare & Loss of integration \\
\hline (Block et al. 2002) & $\begin{array}{l}\text { Posterior } \\
\text { mandible }\end{array}$ & $\begin{array}{l}\text { Complete } \\
\text { Removable }\end{array}$ & Rigid & 3-unit & Screw & 36 months & Omniloc & $\begin{array}{c}\text { Loss of integration } \\
\text { without inflammation }\end{array}$ \\
\hline \multirow[t]{3}{*}{ (Bragger et al. 2005) } & N/A & Fixed & Rigid & $\mathrm{N} / \mathrm{A}$ & $\mathrm{N} / \mathrm{A}$ & $\begin{array}{l}\text { Within } \\
60 \text { months }\end{array}$ & ITI/Straumann & $\begin{array}{l}\text { Primary biological } \\
\text { complication }\end{array}$ \\
\hline & N/A & Fixed & Rigid & $\mathrm{N} / \mathrm{A}$ & $\mathrm{N} / \mathrm{A}$ & $\begin{array}{l}\text { Within } \\
60 \text { months }\end{array}$ & ITI/Straumann & $\begin{array}{l}\text { Bony defect followed } \\
\text { by fracture }\end{array}$ \\
\hline & $\mathrm{N} / \mathrm{A}$ & Fixed & Rigid & $\mathrm{N} / \mathrm{A}$ & $\mathrm{N} / \mathrm{A}$ & $\begin{array}{c}\text { Within } \\
120 \text { months }\end{array}$ & ITI/Straumann & Loss of integration \\
\hline (Cordaro et al. 2005) & $\begin{array}{l}\text { Posterior } \\
\text { Maxilla }\end{array}$ & $\begin{array}{l}\text { Combined fixed } \\
\text { removable } \\
\text { prosthesis }\end{array}$ & Non rigid & 12-unit & $\begin{array}{l}\text { Permanent } \\
\text { Cement }\end{array}$ & 7 months & Straumann & Mobility \\
\hline
\end{tabular}


Table 4. Cont

\begin{tabular}{|c|c|c|c|c|c|c|c|c|}
\hline Author/Year & $\begin{array}{c}\text { Location of } \\
\text { Failed Implant }\end{array}$ & $\begin{array}{l}\text { Opposing } \\
\text { Dentition }\end{array}$ & $\begin{array}{l}\text { Connection } \\
\text { Type }\end{array}$ & $\begin{array}{l}\text { Reconstruction } \\
\text { Length }\end{array}$ & FPD Retention & $\begin{array}{l}\text { Time after } \\
\text { Loading }\end{array}$ & Implant Brand & Reason for Failure \\
\hline & $\mathrm{N} / \mathrm{A}$ & $\mathrm{N} / \mathrm{A}$ & Rigid & $\mathrm{N} / \mathrm{A}$ & $\begin{array}{l}\text { Temporary } \\
\text { Cement }\end{array}$ & N/A & Tiolox & Peri-implant disease \\
\hline \multirow[t]{6}{*}{ (Kindberg et al. 2001) } & Maxilla & N/A & Non rigid & 12-unit & Screw & 36 months & Nobel Biocare & Loss of integration \\
\hline & Maxilla & $\mathrm{N} / \mathrm{A}$ & N/A & N/A & Screw & 36 months & Nobel Biocare & Loss of integration \\
\hline & Maxilla & $\mathrm{N} / \mathrm{A}$ & N/A & N/A & Screw & 36 months & Nobel Biocare & Loss of integration \\
\hline & Maxilla & $\mathrm{N} / \mathrm{A}$ & Rigid & 10-unit & Screw & 60 months & Nobel Biocare & Loss of integration \\
\hline & Maxilla & $\mathrm{N} / \mathrm{A}$ & $\mathrm{N} / \mathrm{A}$ & N/A & Screw & 60 months & Nobel Biocare & Loss of integration \\
\hline & Maxilla & $\mathrm{N} / \mathrm{A}$ & $\mathrm{N} / \mathrm{A}$ & N/A & Screw & 60 months & Nobel Biocare & Loss of integration \\
\hline (Lindh et al. 2001a) & $\begin{array}{l}\text { Posterior } \\
\text { Maxilla }\end{array}$ & $\mathrm{N} / \mathrm{A}$ & Rigid & $\begin{array}{l}\text { Unilateral } \\
\text { short span }\end{array}$ & Screw & Within 3 months & Nobel Biocare & Mobility \\
\hline \multirow[t]{5}{*}{ (Lindh et al. 2001b) } & $\begin{array}{l}\text { Posterior } \\
\text { Maxilla }\end{array}$ & $\mathrm{N} / \mathrm{A}$ & N/A & $\mathrm{N} / \mathrm{A}$ & $\mathrm{N} / \mathrm{A}$ & 12 months & $\begin{array}{l}\text { Straumann or } \\
\text { Nobel Biocare }\end{array}$ & Loss of integration \\
\hline & $\begin{array}{l}\text { Posterior } \\
\text { Maxilla }\end{array}$ & N/A & N/A & $\mathrm{N} / \mathrm{A}$ & $\mathrm{N} / \mathrm{A}$ & 12 months & $\begin{array}{l}\text { Straumann or } \\
\text { Nobel Biocare }\end{array}$ & Loss of integration \\
\hline & Maxilla & $\mathrm{N} / \mathrm{A}$ & $\mathrm{N} / \mathrm{A}$ & N/A & $\mathrm{N} / \mathrm{A}$ & 12 months & $\begin{array}{l}\text { Straumann or } \\
\text { Nobel Biocare }\end{array}$ & Loss of integration \\
\hline & Maxilla & $\mathrm{N} / \mathrm{A}$ & $\mathrm{N} / \mathrm{A}$ & N/A & N/A & 12 months & $\begin{array}{l}\text { Straumann or } \\
\text { Nobel Biocare }\end{array}$ & Loss of integration \\
\hline & Maxilla & $\mathrm{N} / \mathrm{A}$ & $\mathrm{N} / \mathrm{A}$ & N/A & $\mathrm{N} / \mathrm{A}$ & $\mathrm{N} / \mathrm{A}$ & $\begin{array}{l}\text { Straumann or } \\
\text { Nobel Biocare }\end{array}$ & Loss of integration \\
\hline \multirow[t]{3}{*}{ (Naert et al., 1992) } & $\begin{array}{l}\text { Posterior } \\
\text { maxilla }\end{array}$ & $\mathrm{N} / \mathrm{A}$ & Rigid & $\begin{array}{l}\text { Unilateral } \\
\text { short span }\end{array}$ & $\mathrm{N} / \mathrm{A}$ & $\begin{array}{l}\text { Within } \\
36 \text { months }\end{array}$ & Branemark & Fracture \\
\hline & $\begin{array}{c}\text { Posterior } \\
\text { maxilla }\end{array}$ & $\mathrm{N} / \mathrm{A}$ & Rigid & $\begin{array}{l}\text { Unilateral } \\
\text { short span }\end{array}$ & $\mathrm{N} / \mathrm{A}$ & $\begin{array}{c}\text { Within } \\
36 \text { months }\end{array}$ & Branemark & Fracture \\
\hline & Posterior & $\mathrm{N} / \mathrm{A}$ & Rigid & $\begin{array}{l}\text { Unilateral } \\
\text { short span }\end{array}$ & $\mathrm{N} / \mathrm{A}$ & $\begin{array}{l}\text { Within } \\
22 \text { months }\end{array}$ & Branemark & Loss of integration \\
\hline
\end{tabular}


Table 4. Cont

\begin{tabular}{|c|c|c|c|c|c|c|c|c|}
\hline Author/Year & $\begin{array}{c}\text { Location of } \\
\text { Failed Implant }\end{array}$ & $\begin{array}{l}\text { Opposing } \\
\text { Dentition }\end{array}$ & $\begin{array}{l}\text { Connection } \\
\text { Type }\end{array}$ & $\begin{array}{l}\text { Reconstruction } \\
\text { Length }\end{array}$ & FPD Retention & $\begin{array}{l}\text { Time after } \\
\text { Loading }\end{array}$ & Implant Brand & Reason for Failure \\
\hline & Posterior & $\mathrm{N} / \mathrm{A}$ & Rigid & $\begin{array}{l}\text { Unilateral } \\
\text { short span }\end{array}$ & $\mathrm{N} / \mathrm{A}$ & $\begin{array}{c}\text { Within } \\
22 \text { months }\end{array}$ & Branemark & Loss of integration \\
\hline & Posterior & $\mathrm{N} / \mathrm{A}$ & Rigid & $\begin{array}{l}\text { Unilateral } \\
\text { short span }\end{array}$ & $\mathrm{N} / \mathrm{A}$ & $\begin{array}{c}\text { Within } \\
22 \text { months }\end{array}$ & Branemark & Loss of integration \\
\hline \multirow[t]{10}{*}{ (Naert et al. 2001) } & $\mathrm{N} / \mathrm{A}$ & $\mathrm{N} / \mathrm{A}$ & Rigid & $\mathrm{N} / \mathrm{A}$ & Screw & 25-36 months & Branemark & Mobility \\
\hline & $\mathrm{N} / \mathrm{A}$ & $\mathrm{N} / \mathrm{A}$ & Rigid & $\mathrm{N} / \mathrm{A}$ & Screw & $25-36$ months & Branemark & Mobility \\
\hline & $\mathrm{N} / \mathrm{A}$ & $\mathrm{N} / \mathrm{A}$ & Rigid & $\mathrm{N} / \mathrm{A}$ & Screw & $25-36$ months & Branemark & Mobility \\
\hline & $\mathrm{N} / \mathrm{A}$ & $\mathrm{N} / \mathrm{A}$ & Rigid & N/A & Screw & 25-36 months & Branemark & Mobility \\
\hline & $\mathrm{N} / \mathrm{A}$ & $\mathrm{N} / \mathrm{A}$ & Non-rigid & $\mathrm{N} / \mathrm{A}$ & Screw & $49-60$ months & Branemark & Mobility \\
\hline & $\mathrm{N} / \mathrm{A}$ & $\mathrm{N} / \mathrm{A}$ & Non-rigid & N/A & Screw & $49-60$ months & Branemark & Mobility \\
\hline & $\mathrm{N} / \mathrm{A}$ & $\mathrm{N} / \mathrm{A}$ & Rigid & N/A & Screw & 61-72 months & Branemark & Fracture \\
\hline & N/A & $\mathrm{N} / \mathrm{A}$ & Rigid & N/A & Screw & 85-96 months & Branemark & Fracture \\
\hline & $\mathrm{N} / \mathrm{A}$ & $\mathrm{N} / \mathrm{A}$ & Rigid & N/A & Screw & 85-96 months & Branemark & Fracture \\
\hline & $\mathrm{N} / \mathrm{A}$ & $\mathrm{N} / \mathrm{A}$ & Non-rigid & $\mathrm{N} / \mathrm{A}$ & Screw & 85-96 months & Branemark & Fracture \\
\hline \multirow[t]{3}{*}{ (Romeo et al. 2004) } & Mandible & $\mathrm{N} / \mathrm{A}$ & $\mathrm{N} / \mathrm{A}$ & $\mathrm{N} / \mathrm{A}$ & $\mathrm{N} / \mathrm{A}$ & 72-84 months & ITI/Straumann & Peri-implant disease \\
\hline & Maxilla & $\mathrm{N} / \mathrm{A}$ & $\mathrm{N} / \mathrm{A}$ & $\mathrm{N} / \mathrm{A}$ & $\mathrm{N} / \mathrm{A}$ & 36-48 months & ITI/Straumann & Peri-implant disease \\
\hline & Maxilla & $\mathrm{N} / \mathrm{A}$ & N/A & N/A & $\mathrm{N} / \mathrm{A}$ & $48-60$ months & ITI/Straumann & Peri-implant disease \\
\hline \multirow[t]{2}{*}{ (Tangerud et al. 2002) } & Maxilla & $\mathrm{N} / \mathrm{A}$ & Rigid & $\mathrm{N} / \mathrm{A}$ & Screw & 12-24 months & Branemark & Mobility \\
\hline & Maxilla & $\mathrm{N} / \mathrm{A}$ & Rigid & $\mathrm{N} / \mathrm{A}$ & Screw & 24-36 months & Branemark & $\begin{array}{l}\text { Peri-implant } \\
\text { bone loss }\end{array}$ \\
\hline
\end{tabular}


Out of 34 teeth used as abutments in a study by Akca and Cehreli, one tooth needed to be root treated, although none were lost during the observation period. In this study, only four of the teeth used as abutments were previously root canal treated, and none of the teeth used had fractured. There were also no cases of intrusion documented. It is worth noting that the teeth were permanently cemented to the rigid prostheses in all cases [9]. The absence of tooth intrusion was contrary to what was observed in the study by Block et al., where rigid bridges were cemented with temporary cement and petroleum jelly, resulting in a $44 \%$ intrusion rate of rigidly connected teeth, $12.5 \%$ of which showed intrusion of more than $0.5 \mathrm{~mm}$. Although a significant amount of rigidly connected teeth did intrude, this was still less than the $66 \%$ of non-rigidly connected teeth that intruded [31]. In the study by Block et al., RCT teeth were a weak point, with all five fractures occurring in endodontically treated teeth with posts ( 27 of 60 teeth used were RCT). Two fractures occurred in rigidly connected teeth, and three in those non-rigidly connected. In this study, there was significantly more bone loss around rigidly connected teeth than non-rigidly connected teeth [31]. A study by Hosny et al. connected 30 teeth, mostly with rigid connectors to implants. Sixteen of the teeth were temporarily cemented. Despite this, no cement failures were detected, and no teeth intruded. In this study, one tooth developed a periapical lesion 6 months after connection [29].

Similarly, a study of 19 vital teeth by Palmer $e$ al. showed no cases of intrusion even though the rigid frameworks were only temporarily cemented to natural teeth. It is interesting to note that the TIFPs were also temporarily cemented to the implant abutment; thus, when debonding occurred on one abutment, it subsequently occurred on the second abutment, most likely preventing intrusion from occurring. No significant changes in bone level were reported around teeth in this study, and no fractures were observed [8]. Cases of intrusion were also not observed in a study by Heinemann et al., where rigid TIFPs were temporarily cemented to teeth. However, in this study, two teeth needed to be extracted and one endodontically treated [55]. A study by Mundt et al. observed 40 teeth rigidly connected to implants with semi-permanent cement. In this study, no teeth suffered complications, and there were no signs of intrusion. It is worth noting that, in this study, as was the case in the study by Heinemann $e t$ al., the author made use of permanently cemented copings to protect the teeth before cementation of the finished prosthesis [56]. Similar copings were not used in a long-term study by Bragger et al., where 24 natural abutments were rigidly connected to teeth. In this study, four teeth were lost due to caries following loss of retention from the natural abutment despite being permanently cemented. In a number of cases, the bridge was cemented to the implant abutment and could not be removed despite having debonded from the tooth. Most of the lost tooth abutments were previously $\mathrm{RCT}$ and restored with posts [51].

In a study by Lindh et al., 26 Kennedy Class I patients had TIFPs installed on one side of their maxilla, and FSFPs on the contra-lateral side. Twenty-six teeth were connected, of which 15 were endodontically treated, 20 of the natural abutments were canines, 3 premolars, and 3 incisors. In this text, only one tooth fractured after more than 2 years of function. The low fracture rate, despite the number of RCT teeth, as compared to the study of Block et al., may be due to the large number of canines used as abutments. In this study, no tooth mobility and no intrusions were detected, though three teeth devitalized [40].

A study by Ericsson et al. included 29 teeth rigidly or non-rigidly connected to 40 implants in 11 long-span TIFPs. One case of intrusion from a tooth supporting a non-rigid bridge was noted. No loss of alveolar bone was reported around natural abutments throughout the duration of the study, and, apart from the intruded tooth, no other complications were reported [7]. A retrospective study by Cordado et al., which also followed long-span TIFPs rigidly and non-rigidly connected to teeth with healthy and periodontally compromised teeth, observed four cases of intrusion out of a total of 72 connected teeth. Intrusions occurred only in non-rigidly connected teeth and, interestingly, in teeth with healthy periodontia. No cases of intrusion were evident in teeth with reduced periodontal support, suggesting no link between the amount of periodontal support and the likelihood of intrusion. In this study, no teeth developed carious lesions, fractures, or periodontal pathology [35]. 
In a separate retrospective study, 85 teeth were connected to implants in long- and short-span TIFPs. Five teeth were lost due to fracture and endodontic complications. The text also reported no marginal bone loss around teeth after 1 year. There was, however, "minor" bone loss for the 80 teeth reviewed at 3 years, and $2 \mathrm{~mm}$ bone loss around 3 teeth out of the 47 reviewed at 5 years. Three cases of intrusion were detected-one occurred in a case with non-rigid tooth-to-implant connection, and two where non-secured telescopic crowns were used [47]. In a second study by Lindh et al., 220 teeth were connected either rigidly or non-rigidly to implants. Over a three-year observation period, although no teeth were lost, one tooth required endodontic treatment and two teeth developed caries. In this study, 11 teeth showed signs of intrusion. Eight of these teeth were related to prostheses supported by one implant and one tooth. In all cases, the intruded teeth were non-rigidly connected to implants (three with telescopic crowns, four with non-rigid attachments, i.e., without locking screws) or with rigid connectors where the locking screws had fractured $(n=2)$ or loosened $(n=2)$ [50]. On the contrary, four texts followed the same cohort of 23 patients over 10 years, where teeth were permanently cemented to rigid prostheses. In this study, no cases of intrusion were described. However, one tooth was lost due to caries and endodontic problems, which were detected at the ten-year follow up. Only one tooth had more than physiological mobility after 10 years [41-44].

Naert et al. connected 313 teeth to implants in 140 TIFPs, of which 34 were of a non-rigid construction, 49 rigid, and 57 mixed. Nineteen teeth, incorporated in nine separate prostheses, intruded. All of the intruded teeth suffered cement failure and debonded from the prosthesis. Two teeth reviewed in this study fractured, 3 teeth needed extraction due to decay or periodontal problems, and 11 teeth in nine prostheses had periapical pathology [30].

In a 36-month prospective study by Tangerud, 86 teeth, 40 of which were RCT and restored with posts, were rigidly connected to implants. One RCT canine had to be extracted due to fracture, while two teeth developed pockets greater than $5 \mathrm{~mm}$, and one developed a draining sinus. Pockets of $4 \mathrm{~mm}$ or more were found at $22 \%$ of teeth at Year 1 and 19\% at Year 3, while bone reduction was of $0.1 \mathrm{~mm} \pm 0.8 \mathrm{~mm}$ from the time of loading to the 3-year review [52].

In a study by Nickenig et al., 132 abutment teeth were rigidly $(n=56)$ and non-rigidly $(n=28)$ connected to 142 implants in bridges, of which $40 \%$ were three-unit, and 33\% five or more unit. During the observation period, three teeth were lost because of periodontal inflammation or periapical abscess. After 5 years, as many as $8 \%$ of abutment teeth required periodontal treatment, while only three needed restoring and one needed root canal therapy [35].

\subsubsection{Prosthetic Complications}

Twenty texts went into detail regarding the prosthetic complications that arose in 17 patient cohorts over an observation period that varied from 12 to 180 months (Table 6). Out of 676 frameworks reviewed (metal $n=645$, zirconia $n=31$ ), 7 frameworks fractured. Two fractures occurred in rigid zirconia bridges, and five in metal constructions, with two of these fractures occurring around prosthetic attachments. Veneer material fracture was described in 70 cases out of 672 bridges. Bridges were constructed with porcelain $(n=558)$, acrylic $(n=54)$, or composite $(n=38)$ veneering. It is worth noting that 10 veneer fractures occurred in the one study where zirconia frameworks $(n=31)$ were used. Three studies failed to describe the material in which veneer fractures occurred. However, out of the studies that did, ceramic veneer fracture occurred in 46 of 391 TIFPs, while acrylic and composite fracture occurred in 9 of 50 TIFPs. Fifteen fractures in three studies $[47,50,52]$ were not attributed to any material. Despite this, in the study by Lindh et al., the author wrote that "prostheses using metal-ceramic superstructures showed less wear, fewer technical complications, and a higher level of long-lasting esthetic results compared with superstructures using gold-alloy framework and acrylic resin veneers." A similar conclusion was reached in the study by Kindberg et al., which dealt mostly with rigid constructions. This text concluded that prostheses using metal-ceramic superstructures resulted in fewer technical complications, less wear, and longer lasting esthetic results compared to superstructures using gold-alloy framework and acrylic resin veneering. In this study, equal numbers of acrylic and porcelain veneered prostheses were used [47]. 
Table 5. Table of studies detailing failures of natural teeth supporting TIFPs.

\begin{tabular}{|c|c|c|c|c|c|c|c|c|c|c|c|}
\hline Author/Year & Methodology & $\begin{array}{l}\text { No. of } \\
\text { Connected } \\
\text { Teeth }\end{array}$ & $\begin{array}{l}\text { Initial } \\
\text { Periodontal } \\
\text { Condition }\end{array}$ & $\begin{array}{l}\text { Initial } \\
\text { Endodontic } \\
\text { Condition }\end{array}$ & $\begin{array}{l}\text { Method of } \\
\text { Fixation }\end{array}$ & $\begin{array}{l}\text { Lost to } \\
\text { Dental } \\
\text { Caries }\end{array}$ & $\begin{array}{l}\text { Lost to } \\
\text { Periapical } \\
\text { Pathology }\end{array}$ & $\begin{array}{l}\text { Lost to } \\
\text { Tooth } \\
\text { Fracture }\end{array}$ & $\begin{array}{l}\text { Periodontal } \\
\text { Bone Changes }\end{array}$ & $\begin{array}{l}\text { Tooth } \\
\text { Intrusion }\end{array}$ & Observation Period \\
\hline $\begin{array}{l}\text { (Akca and } \\
\text { Cehreli 2008) }\end{array}$ & $\begin{array}{l}\text { Prospective study } \\
\text { comparing TIFPs } \\
\text { and FSFPs. }\end{array}$ & 34 & $\begin{array}{l}\text { crown root } \\
\text { ratio 2:3. }\end{array}$ & 4 RCT, 30 Vital & $\begin{array}{l}\text { Permanent } \\
\text { cement }\end{array}$ & 0 & 0 & 0 & N/A & 0 & $\begin{array}{l}24-30 \text { months (mean } \\
26 \text { months) }\end{array}$ \\
\hline $\begin{array}{l}\text { (Astrand et al. 1991, } \\
\text { Gunne et al. 1992, } \\
\text { Olsson et al. 1995, } \\
\text { Gunne et al. 1999) }\end{array}$ & $\begin{array}{l}\text { Prospective study } \\
\text { comparing TIFPs } \\
\text { and FSFPs, } \\
\text { randomized } \\
\text { cross-arch control. }\end{array}$ & 23 & $\begin{array}{l}\text { Healthy } \\
\text { periodontium. }\end{array}$ & 0 RCT, 23 Vital & $\begin{array}{l}\text { Permanent } \\
\text { cement }\end{array}$ & 1 & & 0 & $\begin{array}{l}\text { Not significantly } \\
\text { different to } \\
\text { control; } 1 \text { tooth } \\
\text { developed } \\
\text { mobility }\end{array}$ & 0 & 120 months \\
\hline (Block et al. 2002) & $\begin{array}{l}\text { Prospective study } \\
\text { comparing rigid and } \\
\text { non-rigid TIFPs. }\end{array}$ & 60 & $\begin{array}{l}\text { Healthy } \\
\text { periodontium } \\
\text { Crown root } \\
\text { ration of at } \\
\text { least 1:2. }\end{array}$ & $\begin{array}{l}27 \mathrm{RCT} \text {, } \\
33 \text { Vital }\end{array}$ & $\begin{array}{l}\text { Permanent } \\
\text { cement for } \\
\text { non-rigid. } \\
\text { Temporary } \\
\text { cement for rigid. }\end{array}$ & 0 & 0 & $\begin{array}{l}2 \text { rigid side } \\
3 \text { non rigid } \\
\text { side(all } \\
\text { RCT) }\end{array}$ & $\begin{array}{l}\text { No significant } \\
\text { bone loss }\end{array}$ & $\begin{array}{l}21 \text { non rigid } \\
\text { cases } 14 \text { rigid } \\
\text { cases. }\end{array}$ & 60 months \\
\hline (Bragger et al. 2005) & $\begin{array}{l}\text { Prospective study } \\
\text { following SC, FSFP } \\
\text { and TIFP } \\
\text { restorations. }\end{array}$ & 24 & $\begin{array}{l}\text { Supportive } \\
\text { periodontal } \\
\text { care given. }\end{array}$ & RCT and vital & $\begin{array}{l}\text { Permanent } \\
\text { cement }\end{array}$ & 4 & 0 & 0 & N/A & 0 & 120 months \\
\hline $\begin{array}{l}\text { (Cordaro et al. } \\
\text { 2005) }\end{array}$ & $\begin{array}{l}\text { Retrospective study } \\
\text { of TIFPs on teeth } \\
\text { with normal and } \\
\text { reduced periodontal } \\
\text { support. }\end{array}$ & 72 & $\begin{array}{l}10 \text { patients had } \\
>2 / 3 \text { residual } \\
\text { periodontium } \\
10 \text { patients } \\
<2 / 3 \text { residual } \\
\text { periodontium }\end{array}$ & N/A & $\begin{array}{l}\text { Permanent } \\
\text { cement for } \\
\text { non-rigid. } \\
\text { Temporary } \\
\text { cement for rigid. }\end{array}$ & 0 & 0 & 0 & N/A & $\begin{array}{l}4 \text { non-rigid } \\
\text { cases with } \\
>2 / 3 \\
\text { periodontal } \\
\text { support }\end{array}$ & $\begin{array}{l}24-94 \text { months (mean } \\
36.5 \text { months) }\end{array}$ \\
\hline $\begin{array}{l}\text { (Ericsson et al. } \\
\text { 1986) }\end{array}$ & $\begin{array}{l}\text { Prospective study } \\
\text { following implants } \\
\text { rigidly and } \\
\text { non-rigidly } \\
\text { connected to teeth. }\end{array}$ & 29 & $\begin{array}{l}\text { Supportive } \\
\text { periodontal } \\
\text { care given }\end{array}$ & N/A & $\mathrm{N} / \mathrm{A}$ & 0 & 0 & 0 & $\begin{array}{l}\text { No loss of } \\
\text { alveolar bone } \\
\text { around teeth. }\end{array}$ & $\begin{array}{l}1 \text { non-rigid } \\
\text { case }\end{array}$ & $\begin{array}{l}6-30 \text { months (mean } \\
17.4 \text { months) }\end{array}$ \\
\hline $\begin{array}{l}\text { (Heinemann } \text { et al. } \\
\text { 2006) }\end{array}$ & $\begin{array}{l}\text { Retrospective } \\
\text { evaluation of } \\
\text { different temporary } \\
\text { cements in TIFP } \\
\text { cases. }\end{array}$ & 108 & N/A & N/A & $\begin{array}{l}\text { Temporary or } \\
\text { semi-permanent } \\
\text { cement. }\end{array}$ & 0 & 2 & & $\mathrm{~N} / \mathrm{A}$ & 0 & 48 months \\
\hline (Hosny et al. 2000) & $\begin{array}{l}\text { Retrospective study } \\
\text { of TIFPs with } \\
\text { cross-arch FSFP } \\
\text { control. }\end{array}$ & 30 & N/A & N/A & $\begin{array}{l}16 \text { Temporary } \\
\text { cement, } \\
14 \text { Permanent } \\
\text { cement }\end{array}$ & 0 & 0 & 0 & N/A & 0 & $\begin{array}{l}\text { 15-168 months } \\
\text { (mean } 78 \text { months) }\end{array}$ \\
\hline
\end{tabular}


Table 5. Cont.

\begin{tabular}{|c|c|c|c|c|c|c|c|c|c|c|c|}
\hline Author/Year & Methodology & $\begin{array}{l}\text { No. of } \\
\text { Connected } \\
\text { Teeth }\end{array}$ & $\begin{array}{l}\text { Initial } \\
\text { Periodontal } \\
\text { Condition }\end{array}$ & $\begin{array}{l}\text { Initial } \\
\text { Endodontic } \\
\text { Condition }\end{array}$ & $\begin{array}{l}\text { Method of } \\
\text { Fixation }\end{array}$ & $\begin{array}{l}\text { Lost to } \\
\text { Dental } \\
\text { Caries }\end{array}$ & $\begin{array}{l}\text { Lost to } \\
\text { Periapical } \\
\text { Pathology }\end{array}$ & $\begin{array}{l}\text { Lost to } \\
\text { Tooth } \\
\text { Fracture }\end{array}$ & $\begin{array}{l}\text { Periodontal } \\
\text { Bone Changes }\end{array}$ & $\begin{array}{l}\text { Tooth } \\
\text { Intrusion }\end{array}$ & Observation Period \\
\hline $\begin{array}{l}\text { (Kindberg et al. } \\
\text { 2001) }\end{array}$ & $\begin{array}{l}\text { Retrospective study } \\
\text { of implants } \\
\text { connected rigidly or } \\
\text { non-rigidly to teeth. }\end{array}$ & 85 & $\begin{array}{l}\text { Healthy } \\
\text { periodontium }\end{array}$ & N/A & $\begin{array}{l}45 \text { screw locked, } \\
\text { cemented or } \\
\text { telescopic }\end{array}$ & 0 & 5 & & $\begin{array}{l}\text { No significant } \\
\text { bone loss }\end{array}$ & $\begin{array}{l}1 \text { non-rigid } \\
\text { case and } 2 \text { in } \\
\text { rigid cases } \\
\text { with non } \\
\text { locked } \\
\text { telescopic } \\
\text { crowns. }\end{array}$ & $\begin{array}{l}14-107 \text { months } \\
\text { (mean } 58.3 \text { months) }\end{array}$ \\
\hline (Lindh et al. 2001a) & $\begin{array}{l}26 \text { TIFPs with } \\
\text { cross-arch control } \\
\text { FSFPs in Kennedy } \\
\text { Class I patients. }\end{array}$ & 26 & $\begin{array}{l}16 \text { intact } \\
\text { periodontia; } \\
10<1 / 4 \text { bone } \\
\text { loss }\end{array}$ & $\begin{array}{l}15 \mathrm{RCT}, 11 \\
\text { Vital }\end{array}$ & $\begin{array}{l}\text { Temporary and } \\
\text { Permanent } \\
\text { cement }\end{array}$ & 0 & 0 & 1 & $\begin{array}{l}\text { No increased } \\
\text { mobility } \\
\text { reported }\end{array}$ & 0 & 24 months \\
\hline (Lindh et al. 2001b) & $\begin{array}{l}\text { Multi-centre } \\
\text { retrospective study } \\
\text { following TIFP }\end{array}$ & 220 & $\begin{array}{l}21 \text { lost }>1 / 3 \\
\text { of their } \\
\text { periodontal } \\
\text { support }\end{array}$ & $\begin{array}{l}49 \text { RCT, } 171 \\
\text { Vital }\end{array}$ & N/A & 0 & 0 & 0 & N/A & $\begin{array}{l}11 \text { all } \\
\text { debonded } \\
\text { from } \\
\text { prosthesis }\end{array}$ & 36 months \\
\hline (Mundt et al. 2013) & $\begin{array}{l}\text { Retrospective } \\
\text { study assessing } \\
\text { zirconia TIFPs. }\end{array}$ & 40 & $\begin{array}{l}\text { No BOP } \\
<4 \mathrm{~mm} \\
\text { probing depth }\end{array}$ & RCT or Vital & $\begin{array}{l}\text { Semi-permanent } \\
\text { cement }\end{array}$ & 0 & 0 & 0 & 3 teeth with BOP & 0 & $\begin{array}{l}\text { 12.7- } 47.9 \text { months } \\
\text { (mean: } 28.8 \text { months) }\end{array}$ \\
\hline (Naert et al. 2001) & $\begin{array}{l}\text { Retrospective } \\
\text { analysis of TIFPs } \\
\text { compared to a } \\
\text { control group } \\
\text { of FSFPs. }\end{array}$ & 313 & $\mathrm{~N} / \mathrm{A}$ & N/A & $\begin{array}{l}46 \text { temporary } \\
\text { cement, } \\
94 \text { permanent } \\
\text { cement }\end{array}$ & 3 & 11 & 2 & $\mathrm{~N} / \mathrm{A}$ & $\begin{array}{l}19 \text { all } \\
\text { debonded } \\
\text { from } \\
\text { prosthesis }\end{array}$ & $\begin{array}{l}18-180 \text { months } \\
\text { (mean } 78 \text { months) }\end{array}$ \\
\hline $\begin{array}{l}\text { (Nickenig et al. } \\
\text { 2006) }\end{array}$ & $\begin{array}{l}\text { Retrospective } \\
\text { analysis of teeth } \\
\text { rigidly and } \\
\text { non-rigidly } \\
\text { connected to } \\
\text { implants. }\end{array}$ & 132 & $\mathrm{~N} / \mathrm{A}$ & N/A & N/A & 0 & 3 & 0 & $\begin{array}{l}10 \text { teeth required } \\
\text { periodontal } \\
\text { treatment }\end{array}$ & 0 & $\begin{array}{l}\text { 26.4-99.6 months } \\
\text { (mean 56.76) }\end{array}$ \\
\hline (Palmer et al. 2005) & $\begin{array}{l}\text { Rigidly connected } \\
\text { teeth and implants } \\
\text { via 3-unit bridges in } \\
\text { Kennedy } \\
\text { Class II cases. }\end{array}$ & 19 & $\begin{array}{l}\text { Healthy } \\
\text { periodontium }\end{array}$ & Vital & $\begin{array}{l}\text { Temporary } \\
\text { cement }\end{array}$ & 0 & 0 & 0 & $\begin{array}{l}\text { No significant } \\
\text { bone loss }\end{array}$ & 0 & 36 months \\
\hline $\begin{array}{l}\text { (Tangerud et al. } \\
\text { 2002) }\end{array}$ & $\begin{array}{l}\text { Prospective study } \\
\text { monitoring } \\
30 \text { rigid TIFPs. }\end{array}$ & 86 & N/A & $\begin{array}{l}40 \mathrm{RCT}, \\
46 \text { Vital }\end{array}$ & Cemented & 0 & 0 & $1 \mathrm{RCT}$ & $\begin{array}{l}\text { Bone reduction } \\
\text { of } 0.1 \mathrm{~mm} \pm \\
0.8 \mathrm{~mm} \text { around } \\
\text { teeth }\end{array}$ & 0 & 36 months \\
\hline
\end{tabular}


In a study by Cordaro et al., which made use of 15 metal-ceramic and 4 metal-composite prostheses, one prosthesis had damage to the composite veneer, which was replaced with porcelain over the existing metal framework. This patient's opposing dentition was made out of a fixed prostheses [34]. Veneer fractures were a common occurrence in a short-term retrospective study by Rammelsberg et al., who observed chipping in seven metal-ceramic prostheses [11], and in a study by Heinemann et al., which exhibited five veneer fractures from a total of 65 metal-ceramic prostheses [55]. In a study by Noda et al., 136 metal-ceramic TIFPs were compared to 13 metal-ceramic FSFPs. In the connected group, there were 22 veneer fractures, compared to 7 fractures in the non-connected group [39]. A study by Lindh et al. using metal-ceramic prostheses did not report any veneer fractures although two temporary cement failures were detected. This study also reported one implant screw fracture compared to three abutment screw fractures in the FSFP group [40].

In the studies reviewed, 18 implant screws, including abutment and prosthesis screws, loosened. Cement failures were evident in 132 abutments, 17 where permanent or semi-permanent cement was used, and 90 were temporary cement was used (80 of which occurred in one study). In 25 cement failures, it was not specified which cement was used. Of the studies reviewed, only one study used temporary cement alone, one study used semi-permanent cement, four studies used permanent cement, and six studies used a number of different cements. The other studies reviewed failed to describe which cement was used.

The importance of cement selection was outlined in a study by Bragger et al. In this study, four cases of cement failure led to loss of the TIFPs due to resultant caries of the abutment teeth. The use of permanent cement on the implant abutment made it difficult to retrieve the prosthesis once debonded from the natural abutment, resulting in decay. In this study, two TIFPs had fracture of the porcelain veneer, which was not sufficient to warrant a remake [51]. The opposite was evident in a study by Palmer et al. In this study, temporary cement was used to secure the prosthesis to the natural tooth and implant abutments. As a result, when bridge decementation occurred in eight subjects, in all except one, decementation happened on both the tooth and implant. In this study, eight bridges displayed chipping of the composite veneering material, which occluded against fixed opposing teeth. None of the abutment teeth developed carious lesions [8].

Four studies reported no prosthetic complications. In these studies, 70 of 74 bridges were metal-ceramic, and 4 of 74 were metal-acrylic. The prostheses used were both of a rigid and non-rigid construction and permanently cemented on 57 natural abutments, temporarily cemented on 16 natural abutments, while no indication was given for 13 abutments. The TIFPs were cemented on some implant abutments and screw-retained on others $[9,29,53,54]$. One long-term study following 23 metal-acrylic TIFPs over 10 years reported few prosthetic complications. In this study, the test group was compared to a control group of 23 FSFPs. The only prosthetic complication related to three loose abutment screws, as compared to two loose abutment screws in the FSFP group [41-44].

As previously described, framework fracture occurred in three studies. In one study, zirconia frameworks were used. This study showed two framework fractures, both in patients with parafunctional habits. Ten veneer fractures also occurred in patients with parafunctional habits [56]. Three metal framework fractures occurred in a study by Naert et al. This study also showed 25 cement failures and three abutment screw fractures in 140 rigid and non-rigid prostheses [30]. The other two framework fractures were reported in a multi-center retrospective study. In this study, the frameworks were most commonly made of a high noble alloy, some were made of titanium, and a few were made of gold. The framework fractures in this study involved the attachment parts of the prostheses [50]. 
Table 6. Table of studies detailing prosthetic failures.

\begin{tabular}{|c|c|c|c|c|c|c|c|c|c|c|c|c|}
\hline \multirow[t]{2}{*}{ Author/Year } & \multicolumn{2}{|c|}{$\begin{array}{l}\text { No. of Tooth- } \\
\text { Implant Prostheses }\end{array}$} & \multirow{2}{*}{$\begin{array}{l}\text { Prostheses } \\
\text { Length }\end{array}$} & \multirow{2}{*}{$\begin{array}{l}\text { Prostheses } \\
\text { Construction }\end{array}$} & \multicolumn{2}{|c|}{ Method of Fixation } & \multirow{2}{*}{$\begin{array}{l}\text { Veneer } \\
\text { Fracture }\end{array}$} & \multirow{2}{*}{$\begin{array}{l}\text { Framework } \\
\text { Fracture }\end{array}$} & \multirow{2}{*}{$\begin{array}{l}\text { CEMENT } \\
\text { FAILURE }\end{array}$} & \multirow{2}{*}{$\begin{array}{l}\text { Implant Screw } \\
\text { Fracture/ } \\
\text { Loosening }\end{array}$} & \multirow{2}{*}{$\begin{array}{l}\text { Opposing } \\
\text { Dentition }\end{array}$} & \multirow{2}{*}{$\begin{array}{l}\text { Observation } \\
\text { Period }\end{array}$} \\
\hline & Rigid & Non-Rigid & & & Tooth & Implant & & & & & & \\
\hline $\begin{array}{l}\text { (Akca and } \\
\text { Cehreli 2008) }\end{array}$ & 34 & 0 & 3-unit & Metal-ceramic & $\begin{array}{l}\text { Permanent } \\
\text { cement }\end{array}$ & $\begin{array}{l}\text { Permanent } \\
\text { cement }\end{array}$ & 0 & 0 & 0 & 0 & $\mathrm{~N} / \mathrm{A}$ & $\begin{array}{l}24-30 \text { months } \\
\text { (mean } \\
26 \text { months) }\end{array}$ \\
\hline $\begin{array}{l}\text { (Astrand et al. } \\
\text { 1991, Gunne et al. } \\
\text { 1992, Olsson et al. } \\
\text { 1995, Gunne et al. } \\
\text { 1999) }\end{array}$ & 23 & 0 & 3-unit & Metal-acrylic & $\begin{array}{l}\text { Permanent } \\
\text { cement }\end{array}$ & Screw & 0 & 0 & 0 & 3 & Removable & 120 months \\
\hline $\begin{array}{l}\text { (Bragger } \text { et al. } \\
\text { 2005) }\end{array}$ & 22 & 0 & $\begin{array}{l}10 \text { 3-unit; } \\
6 \text { 4-unit; } \\
4 \text { 5-unit; } \\
2 \text { 10-unit; }\end{array}$ & Metal-ceramic & $\begin{array}{l}\text { Permanent } \\
\text { cement }\end{array}$ & $\begin{array}{l}10 \text { cement } \\
12 \text { screw }\end{array}$ & 2 & 0 & 4 & 4 & Fixed & 120 months \\
\hline $\begin{array}{l}\text { (Cordaro et al. } \\
\text { 2005) }\end{array}$ & 6 & 13 & 10-14-unit & $\begin{array}{l}15 \text { Metal-ceramic; } \\
4 \text { Metal-composite }\end{array}$ & $\begin{array}{l}\text { Permanent/ } \\
\text { Temporary } \\
\text { cement }\end{array}$ & $\begin{array}{l}12 \\
\text { Permanent/ } \\
\text { Temporary } \\
\text { cement; } \\
7 \text { screw }\end{array}$ & $\begin{array}{l}1 \\
\text { (composite) }\end{array}$ & 0 & N/A & 0 & $\begin{array}{l}14 \text { Fixed; } \\
1 \text { Removable; } \\
4 \text { Mixed }\end{array}$ & $\begin{array}{l}24-94 \text { months } \\
\text { (mean } \\
36.5 \text { months) }\end{array}$ \\
\hline $\begin{array}{l}\text { (Heinemann et al. } \\
\text { 2006) }\end{array}$ & 65 & 0 & $\begin{array}{l}\text { Most four } \\
\text { abutments; } 12 \\
2-3 \text { abutments; } \\
13 \\
>4 \text { abutments }\end{array}$ & Metal-ceramic & $\begin{array}{l}\text { Semi- } \\
\text { permanent/ } \\
\text { Temporary } \\
\text { cement }\end{array}$ & $\begin{array}{l}\text { Semi- } \\
\text { permanent/ } \\
\text { Temporary } \\
\text { cement }\end{array}$ & 5 & 0 & $\begin{array}{l}80 \text { with temp } \\
\text { cement; } 4 \text { with } \\
\text { semi-permanent } \\
\text { cement }\end{array}$ & $\mathrm{N} / \mathrm{R}$ & N/A & 48 months \\
\hline (Hosny et al. 2000) & 14 & 4 & $\begin{array}{l}\text { 63-unit; 6 } \\
\text { 4-unit; 2 5-unit; } \\
\text { 36-unit; } \\
\text { 1 8-unit }\end{array}$ & $\begin{array}{l}14 \text { Metal-cerami; } \\
4 \text { Metal-acrylic }\end{array}$ & $\begin{array}{l}14 \text { Permanent } \\
\text { cement; } \\
16 \text { Temporary } \\
\text { cement }\end{array}$ & Screw & 0 & 0 & 0 & 0 & N/A & $\begin{array}{l}15-168 \text { months } \\
\text { (mean } \\
78 \text { months) }\end{array}$ \\
\hline $\begin{array}{l}\text { (Kindberg et al. } \\
\text { 2001) }\end{array}$ & 40 & 1 & $\begin{array}{l}11 \text { 3-unit; } \\
54 \text {-unit; } \\
25 \text { >5-unit }\end{array}$ & $\begin{array}{l}20 \text { Metal-ceramic } \\
20 \text { Metal-acrylic } \\
1 \text { Metal-composite }\end{array}$ & $\begin{array}{l}45 \text { screw locked } \\
\text { copings. } \\
\text { Cemented and } \\
\text { Telescopic }\end{array}$ & Screw & 4 & 0 & 0 & 1 & N/A & $\begin{array}{l}14 \text { months to } \\
106 \text { months }\end{array}$ \\
\hline $\begin{array}{l}\text { (Lindh et al. } \\
\text { 2001a) }\end{array}$ & 26 & 0 & Unilateral & Metal-ceramic & $\begin{array}{l}\text { Permanent/ } \\
\text { Temporary } \\
\text { cement }\end{array}$ & Screw & 0 & 0 & $\begin{array}{l}2 \text { with } \\
\text { temporary } \\
\text { cement }\end{array}$ & 1 & N/A & 24 months \\
\hline $\begin{array}{l}\text { (Lindh et al. } \\
\text { 2001b) }\end{array}$ & 122 & 16 & $\begin{array}{l}\text { Most } 1 \text { implant } \\
\text { to } 1 \text { tooth }\end{array}$ & $\begin{array}{l}131 \text { Metal-ceramic } \\
7 \text { Metal-acrylic }\end{array}$ & N/A & $\mathrm{N} / \mathrm{A}$ & 3 & $\begin{array}{l}\text { 2(attachment } \\
\text { fractures) }\end{array}$ & 0 & $\begin{array}{l}2 \text { (and } 2 \\
\text { abutment } \\
\text { screws } \\
\text { loosened) }\end{array}$ & $\begin{array}{l}119 \text { Fixed; } \\
19 \text { Removable }\end{array}$ & 36 months \\
\hline
\end{tabular}


Table 6. Cont.

\begin{tabular}{|c|c|c|c|c|c|c|c|c|c|c|c|c|}
\hline \multirow{2}{*}{ Author/Year } & \multicolumn{2}{|c|}{$\begin{array}{l}\text { No. of Tooth- } \\
\text { Implant Prostheses }\end{array}$} & \multirow{2}{*}{$\begin{array}{l}\text { Prostheses } \\
\text { Length }\end{array}$} & \multirow{2}{*}{$\begin{array}{l}\text { Prostheses } \\
\text { Construction }\end{array}$} & \multicolumn{2}{|c|}{ Method of Fixation } & \multirow{2}{*}{$\begin{array}{l}\text { Veneer } \\
\text { Fracture }\end{array}$} & \multirow{2}{*}{$\begin{array}{l}\text { Framework } \\
\text { Fracture }\end{array}$} & \multirow{2}{*}{$\begin{array}{l}\text { CEMENT } \\
\text { FAILURE }\end{array}$} & \multirow{2}{*}{$\begin{array}{l}\text { Implant Screw } \\
\text { Fracture/ } \\
\text { Loosening }\end{array}$} & \multirow{2}{*}{$\begin{array}{l}\text { Opposing } \\
\text { Dentition }\end{array}$} & \multirow{2}{*}{$\begin{array}{l}\text { Observation } \\
\text { Period }\end{array}$} \\
\hline & Rigid & Non-Rigid & & & Tooth & Implant & & & & & & \\
\hline (Mundt et al. 2013) & 31 & 0 & $\begin{array}{l}15 \text { 3-unit; } 4 \\
\text { 4-unit; } 6 \text { 5-unit; } \\
4 \text { 6-unit; } \\
1 \text { 8-unit; } \\
\text { 1 12-unit } \\
\end{array}$ & $\begin{array}{l}\text { Zirconia with } \\
\text { ceramic veneer }\end{array}$ & $\begin{array}{l}\text { Semi- } \\
\text { permanent } \\
\text { cement }\end{array}$ & $\begin{array}{l}\text { Semi- } \\
\text { permanent } \\
\text { cement }\end{array}$ & 10 & 2 & 2 & $\begin{array}{l}1 \text { abutment } \\
\text { screw loosened. }\end{array}$ & Fixed & $\begin{array}{l}12.7-47.9 \\
\text { months (mean } \\
28.8 \text { months) }\end{array}$ \\
\hline \multirow[b]{2}{*}{ (Naert et al. 2001) } & 49 & 34 & \multirow[b]{2}{*}{ N/A } & \multirow[b]{2}{*}{$\begin{array}{l}106 \text { Metal-ceramic } \\
34 \text { Metal- acrylic }\end{array}$} & \multirow[b]{2}{*}{$\begin{array}{l}94 \text { Permanent } \\
\text { cement; } \\
46 \text { Temporary } \\
\text { cement. }\end{array}$} & \multirow[b]{2}{*}{ Screw } & \multirow[b]{2}{*}{ N/A } & \multirow[b]{2}{*}{3} & \multirow[b]{2}{*}{25} & \multirow{2}{*}{$\begin{array}{l}\text { Loose screw not } \\
\text { reported; } \\
\text { despite } 3 \\
\text { abutment screw } \\
\text { fractures }\end{array}$} & \multirow[b]{2}{*}{ N/A } & \multirow[b]{2}{*}{$\begin{array}{l}18-180 \text { months } \\
\text { (mean } \\
78 \text { months) }\end{array}$} \\
\hline & 57 & & & & & & & & & & & \\
\hline (Noda et al. 2013) & 136 & & $\mathrm{~N} / \mathrm{A}$ & Metal-ceramic & $\mathrm{N} / \mathrm{A}$ & $\mathrm{N} / \mathrm{A}$ & 22 & $\mathrm{~N} / \mathrm{A}$ & N/A & $\begin{array}{l}4 \text { of } 58 \text { had } \\
\text { screw loosening }\end{array}$ & $\mathrm{N} / \mathrm{A}$ & $\begin{array}{l}\text { Mean of } \\
37.3 \text { months. }\end{array}$ \\
\hline (Ozkan et al. 2011) & 9 & & N/A & Metal-ceramic & $\begin{array}{l}\text { Permanent } \\
\text { cement }\end{array}$ & $\begin{array}{l}\text { Screw/ } \\
\text { Permanent } \\
\text { cement }\end{array}$ & 0 & 0 & 0 & 0 & $\begin{array}{l}\text { Fixed and } \\
\text { Removable }\end{array}$ & 60 months \\
\hline $\begin{array}{l}\text { (Palmer et al. } \\
\text { 2005) }\end{array}$ & 19 & 0 & Unilateral & Metal-composite & $\begin{array}{l}\text { Temporary } \\
\text { cement }\end{array}$ & $\begin{array}{l}\text { Temporary } \\
\text { cement }\end{array}$ & 8 & 0 & 8 & $\mathrm{~N} / \mathrm{R}$ & Fixed & 36 months \\
\hline $\begin{array}{l}\text { (Rammelsberg } \\
\text { et al., 2013) }\end{array}$ & 48 & 0 & Mostly 3-4-unit & Metal-ceramic & $\begin{array}{l}\text { Permanent/ } \\
\text { Semi- } \\
\text { permanent } \\
\text { cement }\end{array}$ & $\begin{array}{l}\text { Permanent/ } \\
\text { Semi- } \\
\text { permanent } \\
\text { cement }\end{array}$ & 7 & 0 & 3 & $\mathrm{~N} / \mathrm{R}$ & N/A & $\begin{array}{l}\text { Average of } 28 \\
\text { months. }\end{array}$ \\
\hline $\begin{array}{l}\text { (Romeo et al. } \\
\text { 2004) }\end{array}$ & 13 & & N/A & Metal-ceramic & N/A & N/A & 0 & 0 & 0 & 0 & N/A & 46.2 months \\
\hline $\begin{array}{l}\text { (Tangerud et al. } \\
\text { 2002) }\end{array}$ & 30 & 0 & $\begin{array}{l}\text { 3-13 units, } \\
\text { mean } 8.6\end{array}$ & $\begin{array}{l}16 \text { Metal-ceramic, } \\
14 \text { Metal-composite }\end{array}$ & Cement & Screw & 8 & 0 & 0 & 0 & N/A & 36 months \\
\hline
\end{tabular}




\subsection{Survival}

\subsubsection{Overall Survival}

In this review, overall prosthesis survival refers to any TIFP that remained functional in the mouth over the length of the study period, despite any minor complications. Minor complications encountered included: veneer fracture that did not require removal of the prosthesis, screw loosening, cement failure and peri-implant/periodontal bone loss not detrimental to the survival of the prosthesis. In one study, complications were more severe, with implants and/or teeth needing to be extracted. However, in this study, the prostheses could be recemented without needing to be remade. Overall 502 out of 531 TIFPs remained functional in 18 studies that had the data available for review. The main cause of prosthesis failure was loss of the natural abutment due to fracture, caries or periapical pathology $(n=13)$, or loss of the implant abutment $(n=8)$ resulting in insufficient prosthesis support. Other factors that influenced the overall survival included framework fracture $(n=4)$, tooth intrusion $(n=1)$, permanent debonding $(n=1)$, and unspecified technical complications $(n=2)$ as described in the study by Bragger et al. 2005 [51]. The studies reviewed included patients observed for 6 to 158 months. Six studies were not included in this section as it was unclear whether failing complications occurred in the same prosthesis or in different prostheses.

\subsubsection{Complication-Free Survival}

Fifteen studies provided sufficient information regarding complication-free survival. Out of the studies reviewed 336 out of 439 prostheses showed no technical or biological complications and remained functional in the mouth. Ten studies were excluded from this aspect of the literature review due to insufficient information on treatment complications. Such studies often quoted figures according to the type of complication, making it unclear whether more than one complication occurred in the same prosthesis or if the complications were spread between a number of prostheses.

Most complications, which were or were not detrimental to prosthesis survival, were related to veneer fracture or wear $(n=26)$. This was followed by complications related to the natural abutment $(n=17)$ and implant related complications $(n=17)$. Intrusion occurred in 7 cases and retention related complications in 17 cases. Other complications included horizontal screw loosening or fracture $(n=3)$, necessary occlusal adjustments $(n=2)$ and other unspecified complications $(n=16)$. Eighteen cases of abutment fracture in nine patients in a study by Block et al. were excluded due to manufacture defect in the laser weld of the Omniloc abutment [31]. These abutments were eventually replaced with abutments lacking a laser weld and fracture did not re-occur.

\section{Discussion}

The aim of this review was to examine the literature and provide an overview of complications associated with tooth-to-implant-connected fixed partial dentures, as well as to provide information on overall prosthesis survival and complication-free survival. The quality of the evidence comprising this literature review varies. Although the texts included in this review dealt with both prospective and retrospective cohort studies, some incorporated control groups or cross-arch controls, and some studies also randomly assigned different treatments into groups. A number of studies reviewed clearly defined the parameters for data collection. However, in others, results were arbitrary and subject to investigator interpretation. A clear example of this was the measurement of peri-implant bone loss, which was measured using either clinical measurements, radiographs, or, in one study, implant threads, which made distance measurement subjective. This was also evident in a study by Block et al., where study photographs were used to monitor intrusion [31], whereas, in other studies, only clinical observations were used. This lead to a large number of cases of intrusion detected when compared to other studies. In certain studies, it was also unclear who the investigator collecting the data was and whether he was biased. Despite the possible application of this method of treatment in a number of clinical situations, randomized control studies were uncommon. 
This literature review found 25 studies that fit the inclusion criteria. Different methodologies and measured results meant that some texts were excluded from different aspects of this review. A more standardized approach with regard to data collection for dental, periodontal, implant, peri-implant as well as prosthesis conditions from investigators and study authors would simplify and improve interpretation of data for meta-analysis, especially considering the multifaceted nature of TIFP treatment. The different study methodologies and measurements collected meant that it was not possible to undertake a meta-analysis on the results of the papers available in the literature. However, it was possible to follow certain trends and draw relevant conclusions.

Complications of the natural abutments were the most common cause of failure. This was associated with the use of compromised teeth for prosthesis support, resulting in a number of natural abutments being extracted due to fracture or caries. In fact, studies that made use of predominately vital abutments over RCT teeth reported no tooth fractures $[8,9,44,50]$. This evidence is what may be expected and is similar to what has been documented for conventional FPDs. In this review, $1.2 \%$ of abutment teeth fractured, whereas $2.1 \%$ in a review of conventional FPDs [57]. Out of the 16 documented natural tooth fractures in this review, 6 were previously RCT, while the endodontic status of the other 10 fractured teeth was not specified.

Dental caries developed in a number of situations where loss of retention on the natural abutment went unnoticed due to retention of the prosthesis on the implant. This was evident in the study by Bragger et al., where four carious lesions started following a loss of retention and eventually led to the same four cases, losing the related implants and corresponding prostheses. It is worth mentioning that in this study most of the lost natural abutments were RCT and restored with cast posts and cores [51]. Apart from the risk of caries, debonding of the prosthesis from the natural abutment led to the intrusion of teeth [30,31]. Intrusion was also evident when teeth were intentionally connected to implants in a non-rigid manner [34] or when two-piece rigid prostheses became non-rigid due to loosening/fracture of the attachment screw [50]. From this review, it is possible to say that, when implants were rigidly connected to teeth, intrusion was rarely reported, although it must be considered that this may be due to difficulty in actually visualizing and detecting intrusion in rigid cases. With this in mind, it may be advantageous to ensure that the tooth is permanently cemented to the prosthesis, despite possible concerns with prosthesis retrievability. From the observations in this review, it is impossible to deduce the etiology of intrusion.

Although limited data was available, no prostheses were lost due to periodontal complications resulting from connecting teeth to implants, and reported cases of periodontitis were uncommon. However, this may have been due to the fact that observing the periodontal condition was not a priority of the studies included in this review.

As described in Table 7, no single method of connecting teeth to TIFPs is ideal in all respects, and it is up to the clinician to best evaluate the clinical scenario and decide on the mode of connection that best suits the case.

Table 7. Advantages and disadvantages of methods to secure a TIFP to a natural abutment.

\begin{tabular}{|c|c|c|c|c|}
\hline & Intrusion & Retrievability & Caries Risk & Technical Complications \\
\hline Temporary Cement & Likely & Good & Moderate & Low \\
\hline Permanent Cement & Unlikely & Poor & Low & Low \\
\hline Temporarily Cemented telescopic crowns & Possible & Good & Low & Low \\
\hline Screw retained on coping & Possible & Good & Low & High \\
\hline Permanent cement with locked TIFP attachment & Possible & Good & Low & High \\
\hline
\end{tabular}

Prosthesis design is a disputed aspect of TIFP treatment. Most controversy is centered on the rigidity of the superstructure. As previously described, the main reason behind this controversy is the mismatch in mobility between implants and teeth. This mismatch theoretically causes the tooth to act as a cantilever and the implant to bear most of the force whenever a rigid connection is employed [9]. The consequences of this may be marginal bone loss or technical complications related to the implant (Table 8). This has led some clinicians to non-rigidly connect implants and teeth. Despite 
the theoretical reasoning, the reviewed studies showed a negative trend when it came to non-rigid connection of teeth to implants. Apart from the increased evidence of dental intrusion when teeth were non-rigidly connected to implants [7,31,34], studies show more complications and more inter-review appointments needed to deal with technical complications [10,31,35,51]. In the study by Nickenig et al., only 3 of 56 rigid TIFPs were affected by technical complications, while 8 of 28 non-rigid TIFPs needed modification [35]. Technical complications were also evident when attachments were used, which were locked to form a rigid prosthesis [42,50].

Table 8. Advantages and disadvantages of rigid and non-rigid constructions.

\begin{tabular}{cccc}
\hline & Intrusion & Biological Complications & Technical Complications \\
\hline Rigid construction & Unlikely & No difference & Low \\
\hline Non-Rigid construction & Likely & No difference & High \\
\hline
\end{tabular}

From this review, it was evident that prosthesis framework fractures were rare occurrences, with only seven fractures described. Two framework fractures occurred in the only study that used rigid Zirconia bridges [56], and the other five occurred in metal constructions, with two of these fractures occurring around prosthetic attachments [50]. In light of the limited evidence on Zirconia TIFPs, it may be recommended that this material is used with caution. As may be expected, veneer fracture was a more common complication. Although the number of patients treated with composite or acrylic bridges was limited, it was noted that more composite/acrylic fractures $(n=9 / 50)$ occurred than when porcelain veneering was used $(n=46 / 391)$. Fifteen fractures were not attributed to any material. As may be expected, there were also fewer complications related to wear and esthetics when porcelain veneering was used. In light of the evidence in this literature review, it may be advisable to utilize rigid metal frameworks veneered with porcelain in TIFP cases.

The studies included in this literature review also demonstrated positive outcomes for the implant abutment and peri-implant bone. Concerns about the bending forces on the prosthetic components and on the implant itself were not clinically manifested. This literature review found a low incidence of prosthetic screw fracture, as well as implant fracture, which was comparable to that found in literature reviews of FSFPs. In a literature review by Pjetursson et al. on implant- implant-supported FPDs, fracture of implants was a rare complication with a cumulative incidence of $0.4 \%$ (95\% CI: $0.1-1.2 \%)$ after 5 years and $1.8 \%(95 \%$ CI: 1.2-2.6\%) after 10 years [58]. In this literature review, implant fracture occurred in 7 of the 1610 implants reviewed $(0.4 \%)$. Despite the positive outcomes for the implant abutments, a number of early implant loses (Table 4) may have been avoided by clinically testing the level of osseointegration before connecting the implant to a naturally mobile tooth abutment. The need to ascertain osseointegration may be more important in TIFP cases as opposed to FSFP cases were both abutments are rigid.

Marginal bone loss around fixtures, exceeding the parameters set by Albrektsson for implant success was rare [48], with some studies also demonstrating an overall increase in marginal bone levels $[8,9]$. In other studies, the level of fixture marginal bone loss was lower in TIFP cases than in FSFP cases $[9,44,50]$. This mismatch in marginal bone loss between FSFP cases and TIFP cases may be due to decreased occlusal forces on TIFP prosthesis as a result of proprioceptive feedback from the PDL of the natural abutment. Similarly, studies exploring marginal bone level changes in implants supporting cantilevered prostheses also demonstrate no significant differences in bone level in implants supporting prostheses without cantilevers [59-61]. However, prosthetic complications are increased in cantilevered prostheses [62]. To better understand the clinical relevance of tooth-to-implant prosthetic treatment, clinical studies should be carried out comparing this method of treatment to cantilevered implant prostheses, preferably in randomized cross-arch studies.

\section{Conclusions}

Clinical implications: Although based on a limited number of cohort studies, with small sample sizes, it can be concluded that connecting teeth to implants is a viable treatment option, 
as agreed on by the authors of the studies reviewed. A number of texts included in this study recommended rigid connection of the natural and fixture abutments in order to avoid intrusion of the natural abutment $[8,9,11,40,44,51,52]$. There was also a trend for investigators to restore using a metal framework veneered in porcelain $[29,34,40,50]$.

A number of authors from the studies selected expressed concern about the reduced retrievability resulting from permanently cementing TIFPs to the natural abutment $[8,29,31,47]$. Despite this, it may be advisable to permanently cement a rigid one-piece casting to the natural abutment to avoid a number of possible technical complications. These complications include failure of temporary cement, fracture of attachments, loosening or fracture of attachment screws, and fracture of veneering material. Due to poor retrievability of permanently cemented one-piece prostheses, this treatment should be avoided in smokers or patients with less than optimal oral hygiene, as removal of the prosthesis for peri-implant treatment would be difficult. It is also advisable to avoid the inclusion of teeth with poor prognosis, mainly RCT teeth, to ensure a favorable long-term prognosis for TIFPs.

From this review, it is possible to conclude that rigid TIFPs, permanently secured to teeth with sufficient coronal structure, while restricting the use of attachments in patients with good oral hygiene and sound implant positioning offer a good long-term treatment option for patients where solely free-standing implant-supported options may not be possible.

Further research: Larger randomized control studies and other clinical studies with fewer variables are required. Studies comparing tooth-to-implant-connected treatment with other forms of treatment including implant-supported cantilevered prostheses are needed to better understand the place of TIFP treatment in oral rehabilitation. Further studies should present standardized results regarding all aspects of TIFP treatment.

Conflicts of Interest: The authors declare no conflict of interest.

\section{Appendix 1: Data Extraction Spreadsheet}
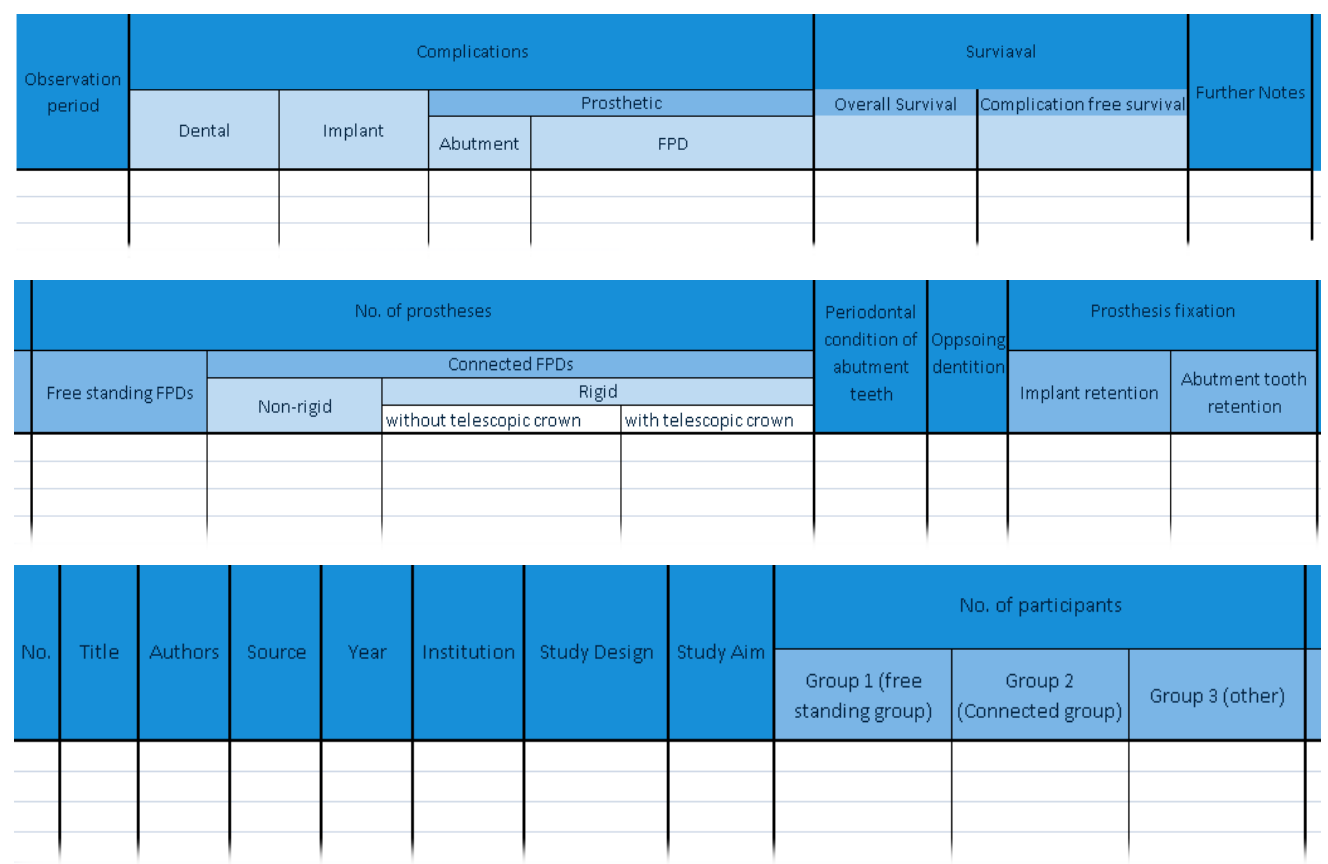

\section{References}

1. Adell, R.; Lekholm, U.; Rockler, B.; Branemark, P. A 15-year study of osseointegrated implants in the treatment of the edentulous jaw. Int. J. Oral Surg. 1981, 10, 387-416. [CrossRef] 
2. Johns, R.; Jemt, T.; Heath, M.; Hutton, J.; McKenna, S.; McNamara, D.; van Steenberghe, D.; Taylor, R.; Watson, R.; Herrmann, I. A multicenter study of overdentures supported by Branemark implants. Int. J. Oral Maxillofac. Implants 1992, 7, 513-522. [CrossRef] [PubMed]

3. Pjetursson, B.; Thoma, D.; Jung, R.; Zwahlen, M.; Zembic, A. A systematic review of the survival and complication rates of implant-supported fixed dental prostheses (FDPs) after a mean observation period of at least 5 years. Clin. Oral Implants Res. 2012, 23, 22-38. [CrossRef] [PubMed]

4. Berglundh, T.; Persson, L.; Klinge, B. A systematic review of the incidence of biological and technical complications in implant dentistry reported in prospective longitudinal studies of at least 5 years. J. Clin. Periodontol. 2002, 29, 197-212. [CrossRef] [PubMed]

5. Buser, D.; Janner, S.; Wittneben, J.; Bragger, U.; Ramseier, C.; Salvi, G. 10-year survival and success rates of 511 titanium implants with a sandblasted and acid-etched surface: A retrospective study in 303 partially edentulous patients. Clin. Implant Dent. Relat. Res. 2012, 14, 839-851. [CrossRef] [PubMed]

6. Spear, F. Connecting teeth to implants The truth about a debated technique. J. Am. Dent. Assoc. 2009, 140, 587-593. [CrossRef] [PubMed]

7. Ericsson, I.; Lekholm, U.; Branemark, P.; Lindhe, J.; Glantz, P.; Nyman, S. A Clinical-evaluation of fixed-bridge restorations supported by the combination of teeth and osseointegrated titanium implants. J. Clin. Periodontol. 1986, 13, 307-312. [CrossRef] [PubMed]

8. Palmer, R.; Howe, L.; Palmer, P. A prospective 3-year study of fixed bridges linking Astra Tech ST implants to natural teeth. Clin. Oral Implants Res. 2005, 16, 302-307. [CrossRef] [PubMed]

9. Akca, K.; Cehreli, M. 2-year prospective follow-up of implant/tooth-supported versus freestanding implant-supported fixed partial dentures. Int. J. Periodontics Restor. Dent. 2008, 28, 593-599.

10. Nickenig, H.; Spiekermann, H.; Wichmann, M.; Andreas, S.; Eitner, S. Survival and complication rates of combined tooth-implant-supported fixed and removable partial dentures. Int. J. Prosthodont. 2008, 21, 131-137. [PubMed]

11. Rammelsberg, P.; Schwarz, S.; Schroeder, C.; Bermejo, J.; Gabbert, O. Short-term complications of implant-supported and combined tooth-implant-supported fixed dental prostheses. Clin. Oral Implants Res. 2013, 24, 758-762. [CrossRef] [PubMed]

12. Iacono, V.; Cochran, D. State of the science on implant dentistry: A workshop developed using an evidence-based approach. Int. J. Oral Maxillofac Implants 2007, 22, 7-10. [PubMed]

13. Lang, N.; Berglundh, T.; Heitz-Mayfield, L.; Pjetursson, B.; Salvi, G.; Sanz, M. Consensus statements and recommended clinical procedures regarding implant survival and complications. Int. J. Oral Maxillofac Implants 2004, 19, 150-154. [PubMed]

14. Salvi, G.; Bragger, U. Mechanical and technical risks in implant therapy. Int. J. Oral Maxillofac Implants 2009, 24, 69-85. [PubMed]

15. Ghodsi, S.; Rasaeipour, S. Tooth-implant connection: A literature review. World J. Dent. 2012, 3, $213-219$. [CrossRef]

16. Cavicchia, F.; Bravi, F. Free-standing vs tooth-connected implant supported fixed partial restorations: A comparative retrospective clinical study of the prosthetic results. Int. J. Oral Maxillofac Implants 1994, 9, 711-718.

17. Sekine, H.; Komiyama, Y.; Potta, H.; Yoshida, K. Mobility characteristics and tactile sensitivity of osseointegrated fixture-supporting systems. In Tissue Integration in Oral Maxillofacial Reconstruction; van Steenberghe, D.M., Ed.; Elsiver: Amsterdam, The Netherlands, 1986; pp. 326-332.

18. Natali, A.; Pavan, P.; Scarpa, C. Numerical analysis of tooth mobility: Formulation of a non-linear constitutive law for the periodontal ligament. Dent. Mater. J. 2004, 20, 623-629. [CrossRef] [PubMed]

19. Komiyama, Y. Clinical and research experience with osseointegrated implants in Japan. In The Branemark Osseointegrated Implant; Albrektsson, T., Zarb, G., Eds.; Quintessence Publ Co., Inc.: Chicago, IL, USA, 1989; pp. 197-214.

20. Skalak, R. Biomechanical considerations in osseointegrated prostheses. J. Prosthet. Dent. 1983, 49, 843-848. [CrossRef]

21. Finger, I.; Guerra, L. Prosthetic considerations in reconstructive implantology. Dent. Clin. North Am. 1986, 30, 69-83. [PubMed]

22. Sullivan, D. Prosthetic considerations for the utilization of osseointegrated fixtures in the partially edentulous arch. Int. J. Oral Maxillofac Implants 1986, 1, 39-45. [PubMed] 
23. Gross, M.; Laufer, B. Splinting osseointegrated implants and natural teeth in rehabilitation of partially edentulous patients. 1: Laboratory and clinical studies. J. Oral Rehabil. 1997, 24, 863-870. [CrossRef] [PubMed]

24. Lang, N.; Pjetursson, B.; Tan, K.; Bragger, U.; Egger, M.; Zwahlen, M. A systematic review of the survival and complication rates of fixed partial dentures (FPDs) after an observation period of at least 5 years-II. Combined tooth-implant-supported FPDs. Clin. Oral Implants Res. 2004, 15, 643-653. [CrossRef] [PubMed]

25. Misch, C. Contemporary Implant Dentistry, 3rd ed.; Mosby: Maryland Heights, MO, USA, 2008.

26. Rangert, B.; Gunne, J.; Sullivan, D. Mechanical aspects of a branemark implant connected to a natural tooth an in vitro study. Int. J. Oral Maxillofac Implants 1991, 6, 177-186. [PubMed]

27. Rangert, B.; Gunne, J.; Glantz, P.; Svensson, A. Vertical load distribution on a 3-unit prosthesis supported by a natural tooth and a single branemark implant-an in vitro study. Clin. Oral Implants Res. 1995, 6, 40-46. [CrossRef] [PubMed]

28. Michalakis, K.; Calvani, P.; Hirayama, H. Biomechanical considerations on tooth-implant supported fixed partial dentures. J. Dent. Biomech. 2012, 3, 1758736012462025. [CrossRef] [PubMed]

29. Hosny, M.; Duyck, J.; van Steenberghe, D.; Naert, I. Within-subject comparison between connected and nonconnected tooth-to-implant fixed partial prostheses: Up to 14-year follow-up study. Int. J. Prosthodont. 2000, 13, 340-346. [PubMed]

30. Naert, I.; Duyck, J.; Hosny, M.; Quirynen, M.; van Steenberghe, D. Freestanding and tooth-implant connected prostheses in the treatment of partially edentulous patients Part II: An up to 15-years radiographic evaluation. Clin. Oral Implants Res. 2001, 12, 245-251. [CrossRef] [PubMed]

31. Block, M.; Lirette, D.; Gardiner, D.; Li, L.; Finger, I.; Hochstedler, J.; Evans, G.; Kent, J.; Misiek, D.; Mendez, A.; et al. Prospective evaluation of implants connected to teeth. Int. J. Oral Maxillofac Implants 2002, 17, 473-487. [PubMed]

32. Richter, E.; Orschall, B.; Jovanovic, S. Dental implant abutment resembling the 2-phase tooth mobility. J. Biomech. 1990, 23, 297-306. [CrossRef]

33. Vanrossen, I.; Braak, L.; Deputter, C.; Degroot, K. Stress-absorbinelements in dental implants. J. Prosthet. Dent. 1990, 64, 198-205. [CrossRef]

34. Cordaro, L.; Ercoli, C.; Rossini, C.; Torsello, F.; Feng, C. Retrospective evaluation of complete-arch fixed partial dentures connecting teeth and implant abutments in patients with normal and reduced periodontal support. J. Prosthet. Dent. 2005, 94, 313-320. [CrossRef] [PubMed]

35. Nickenig, H.; Schaefer, C.; Spiekermann, H. Survival and complication rates of combined tooth-implantsupported fixed partial dentures. Clin. Oral Implants Res. 2006, 17, 506-511. [CrossRef] [PubMed]

36. Lin, C.; Wang, J.; Chang, W. Biomechanical interactions in tooth-implant-supported fixed partial dentures with variations in the number of splinted teeth and connector type: A finite element analysis. Clin. Oral Implants Res. 2008, 19, 107-117. [CrossRef] [PubMed]

37. Chee, W.; Mordohai, N. Tooth-to-implant connection: A systematic review of the literature and a case report utilizing a new connection design. Clin. Implant Dent. Relat. Res. 2010, 12, 122-133. [CrossRef] [PubMed]

38. Pesun, I. Intrusion of teeth in the combination implant-to-natural-tooth fixed partial denture: A review of the theories. J. Prosthodont. 1997, 6, 268-277. [CrossRef] [PubMed]

39. Noda, K.; Arakawa, H.; Maekawa, K.; Hara, E.; Yamazaki, S.; Kimura-Ono, A.; Sonoyama, W.; Minakuchi, H.; Matsuka, Y.; Kuboki, T. Identification of risk factors for fracture of veneering materials and screw loosening of implant-supported fixed partial dentures in partially edentulous cases. J. Oral Rehabil. 2013, 40, 214-220. [CrossRef] [PubMed]

40. Lindh, T.; Back, T.; Nystrom, E.; Gunne, F. Implant versus tooth-implant supported prostheses in the posterior maxilla: A 2-year report. Clin. Oral Implants Res. 2001, 12, 441-449. [CrossRef] [PubMed]

41. Astrand, P.; Borg, K.; Gunne, J.; Olsson, M. Combination of natural teeth and osseointegrated implants as prosthesis abutments: A 2-year longitudinal study. Int. J. Oral Maxillofac Implants 1991, 6, 305-312. [PubMed]

42. Gunne, J.; Astrand, P.; Ahlen, K.; Borg, K.; Olsson, M. Implants in partially edentulous patients. A longitudinal study of bridges supported by both implants and natural teeth. Clin. Oral Implants Res. 1992, 3, 49-56. [CrossRef] [PubMed]

43. Olsson, M.; Gunne, J.; Astrand, P.; Borg, K. Bridges supported by freestanding implants versus bridges supported by tooth and implant a 5-year prospective study. Clin. Oral Implants Res. 1995, 6, 114-121. [CrossRef] [PubMed] 
44. Gunne, J.; Astrand, P.; Lindh, T.; Borg, K.; Olsson, M. Tooth-implant and implant supported fixed partial dentures: A 10-year report. Int. J. Prosthodont. 1999, 12, 216-221. [PubMed]

45. Downs, S.; Black, N. The feasibility of creating a checklist for the assessment of the methodological quality both of randomised and non-randomised studies of health care interventions. J. Epidemiol. Community H 1998, 52, 377-384. [CrossRef]

46. Naert, I.; Quirynen, M.; Schepers, E.; Vansteenberghe, D.; Darius, P. A 6-year prosthodontic study of 509 consecutively inserted implants for the treatment of partial edentulism. J. Prosthet. Dent. 1992, 67, 236-245. [CrossRef]

47. Kindberg, H.; Gunne, J.; Kronstrom, M. Tooth- and implant-supported prostheses: A retrospective clinical follow-up up to 8 years. Int. J. Prosthodont. 2001, 14, 575-581. [PubMed]

48. Albrektsson, T.; Zarb, G.; Worthington, P.; Eriksson, A. The long-term efficacy of currently used dental implants: A review and proposed criteria of success. Int. J. Oral Maxillofac Implants 1986, 1, 11-25. [PubMed]

49. Koczorowski, R.; Surdacka, A. Evaluation of bone loss at single-stage and two-stage implant abutments of fixed partial dentures. Adv. Med. Sci. 2006, 51 (Suppl. 1), 43-45.

50. Lindh, T.; Dahlgren, S.; Gunnarsson, K.; Josefsson, T.; Nilson, H.; Wilhelmsson, P.; Gunne, J. Tooth-implant supported fixed prostheses: A retrospective multicenter study. Int. J. Prosthodont. 2001, 14, 321-328. [PubMed]

51. Bragger, U.; Karoussis, I.; Persson, R.; Pjetursson, B.; Salvi, G.; Lang, N. Technical and biological complications / failures with single crowns and fixed partial dentures on implants: A 10-year prospective cohort study. Clin. Oral Implants Res. 2005, 16, 326-334. [CrossRef] [PubMed]

52. Tangerud, T.; Gronningsaeter, A.; Taylor, A. Fixed partial dentures supported by natural teeth and Branemark system implants: A 3-year report. Int. J. Oral Maxillofac Implants 2002, 17, 212-219.

53. Ozkan, Y.; Akoglu, B.; Kulak-Ozkan, Y. Five-year treatment outcomes with four types of implants in the posterior maxilla and mandible in partially edentulous patients: A retrospective study. Int. J. Oral Maxillofac Implants 2011, 26, 639-647. [PubMed]

54. Romeo, E.; Lops, D.; Margutti, E.; Ghisolfi, M.; Chiapasco, M.; Vogel, G. Long-term survival and success of oral implants in the treatment of full and partial arches: A 7-year prospective study with the ITI dental implant system. Int. J. Oral Maxillofac Implants 2004, 19, 247-259. [PubMed]

55. Heinemann, F.; Mundt, T.; Biffar, R. Retrospective evaluation of temporary cemented, tooth and implant supported fixed partial dentures. J. Craniomaxillofac. Surg. 2006, 34, 86-90. [CrossRef]

56. Mundt, T.; Heinemann, F.; Schankath, C.; Schwahn, C.; Biffar, R. Retrospective and clinical evaluation of retrievable, tooth-implant supported zirconia-ceramic restorations. Acta Odontol. Scand. 2013, 71, 1326-1334. [CrossRef] [PubMed]

57. Tan, K.; Pjetursson, B.; Lang, N.; Chan, E. A systematic review of the survival and complication rates of fixed partial dentures (FPDs) after an observation period of at least 5 years-III. Conventional FPDs. Clin. Oral Implants Res. 2004, 15, 654-666. [CrossRef] [PubMed]

58. Pjetursson, B.; Tan, K.; Lang, N.; Bragger, U.; Egger, M.; Zwahlen, M. A systematic review of the survival and complication rates of fixed partial dentures (FPDs) after an observation period of at least 5 years-I. Implant-supported FPDs. Clin. Oral Implants Res. 2004, 15, 625-642. [CrossRef] [PubMed]

59. Wennstrom, J.; Zurdo, J.; Karlsson, S.; Ekestubbe, A.; Grondahl, K.; Lindhe, J. Bone level change at implant-supported fixed partial dentures with and without cantilever extension after 5 years in function. J. Clin. Periodontol. 2004, 31, 1077-1083. [CrossRef] [PubMed]

60. Haelg, G.; Schmid, J.; Haemmerle, C. Bone level changes at implants supporting crowns or fixed partial dentures with or without cantilevers. Clin. Oral Implants Res. 2008, 19, 983-990. [CrossRef] [PubMed]

61. Romeo, E.; Tomasi, C.; Finini, I.; Casentini, P.; Lops, D. Implant-supported fixed cantilever prosthesis in partially edentulous jaws: A cohort prospective study. Clin. Oral Implants Res. 2009, 20, 1278-1285. [CrossRef] [PubMed]

62. Torrecillas-Martinez, L.; Monje, A.; Lin, G.; Suarez, F.; Ortega-Oiler, I.; Galindo-Moreno, P.; Wang, H. Effect of cantilevers for implant-supported prostheses on marginal bone loss and prosthetic complications: Systematic review and meta-analysis. Int. J. Oral Maxillofac Implants 2014, 29, 1315-1321. [PubMed]

(C) 2016 by the authors; licensee MDPI, Basel, Switzerland. This article is an open access article distributed under the terms and conditions of the Creative Commons Attribution (CC-BY) license (http://creativecommons.org/licenses/by/4.0/). 